Florida International University

FIU Digital Commons

FIU Electronic Theses and Dissertations

University Graduate School

$10-25-2018$

\title{
Chiyo-ni and Yukinobu: History and Recognition of Japanese Women Artists
}

Kara N. Medema

Florida International University, kmede006@fiu.edu

Follow this and additional works at: https://digitalcommons.fiu.edu/etd

Part of the Asian Art and Architecture Commons, and the Asian History Commons

\section{Recommended Citation}

Medema, Kara N., "Chiyo-ni and Yukinobu: History and Recognition of Japanese Women Artists" (2018). FIU Electronic Theses and Dissertations. 3914.

https://digitalcommons.fiu.edu/etd/3914

This work is brought to you for free and open access by the University Graduate School at FIU Digital Commons. It has been accepted for inclusion in FIU Electronic Theses and Dissertations by an authorized administrator of FIU Digital Commons. For more information, please contact dcc@fiu.edu. 


\title{
FLORIDA INTERNATIONAL UNIVERSITY
}

Miami, Florida

\section{CHIYO-NI AND YUKINOBU: HISTORY AND RECOGNITION OF JAPANESE WOMEN ARTISTS}

\author{
A thesis submitted in partial fulfillment of \\ the requirements for the degree of \\ MASTER OF ARTS \\ in
}

ASIAN STUDIES

by

Kara Nicole Medema 
To: Dean John F. Stack, Jr.

Steven J. Green School of International and Public

This thesis, written by Kara Medema, and entitled Chiyo-ni and Yukinobu: History and Recognition of Japanese Women Artists, having been approved in respect to style and intellectual content, is referred to you for judgment.

We have read this thesis and recommend that it be approved.

$\begin{array}{r}\hline \text { Steven Heine } \\ \hline \text { Matthew Marr } \\ \hline \text { Amy Bliss Marshall, Major Professor }\end{array}$

Date of Defense: October 25, 2018

The thesis of Kara Nicole Medema is approved.

Dean John F. Stack, Jr. Steven J. Green School of International and Public Affairs

Andrés G. Gil

Vice President for Research and Economic Development and Dean of the University Graduate School

Florida International University, 2018 


\section{DEDICATION}

I dedicate this thesis to my mother, Debra Furst; my sister, Nina Botello; my nephews Cruz and Cooper; and my husband/personal editor, Aaron Valle. 


\section{ACKNOWLEDGMENTS}

I would like to thank Dr. Steven Heine for his guidance throughout my time at FIU, and for always being "pepper” when he knew I could do better. Thank you also to Dr. Amy Bliss Marshall, for inspiring my topic with her course on women, and for being the first to say "ganbare" when I really needed it. And Dr. Marr, thanks for opening my mind to thinking sociologically and for your constructive feedback and encouragement throughout this process. 


\section{ABSTRACT OF THE THESIS \\ CHIYO-NI AND YUKINOBU: HISTORY AND RECOGNITION \\ OF JAPANESE WOMEN ARTISTS}

By

Kara Nicole Medema

Florida International University, 2018

Miami, Florida

\section{Professor Amy Bliss Marshall, Major Professor}

Fukuda Chiyo-ni and Kiyohara Yukinobu were 17th-18th century (Edo period) Japanese women artists well known during their lifetime but are relatively unknown today. This thesis establishes their contributions and recognition during their lifespans. Further, it examines the precedence for professional women artists' recognition within Japanese art history. Then, it proceeds to explain the complexities of Meiji-era changes to art history and aesthetics heavily influenced by European and American (Western) traditions. Using aesthetic and art historical analysis of artworks, this thesis establishes a pattern of art canon formation that favored specific styles of art/artists while excluding others in ways sometimes inauthentic to Japanese values. Japan has certainly had periods of female suppression and this research illustrates how European models and traditions of art further shaped the perception of Japanese women artists and the dearth of female representation in galleries and art historical accounts. 


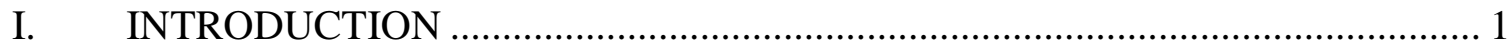

II. THE WOMEN ARTISTS OF EDO: CHIYO-NI AND YUKINOBU ………......... 6

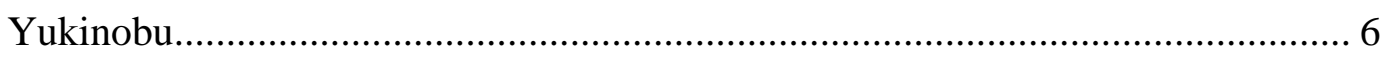

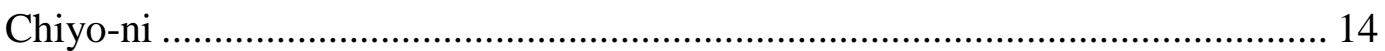

III. JAPANESE WOMEN ARTISTS FROM HEIAN TO AZUCHI-MOMOYAMA 23

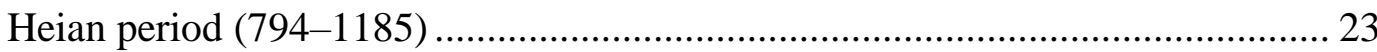

Kamakura to Azuchi-Momoyama period (1185-1600)....................................... 27

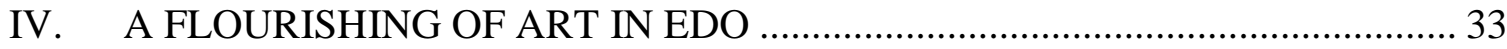

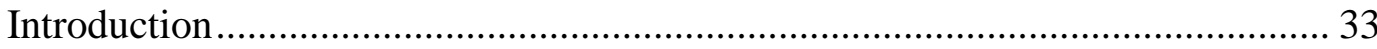

The State of Society in Edo ........................................................................ 34

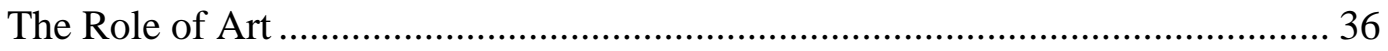

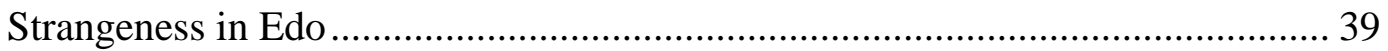

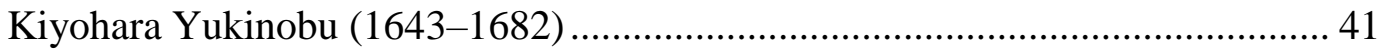

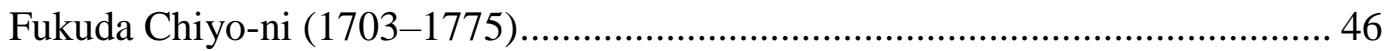

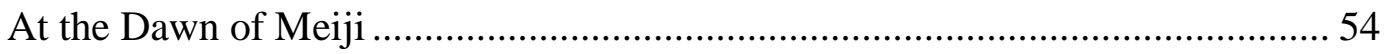

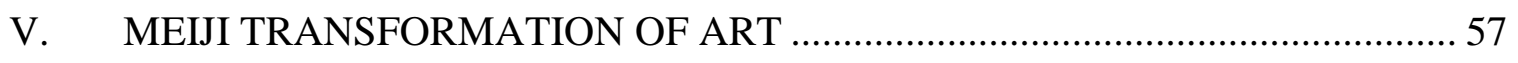

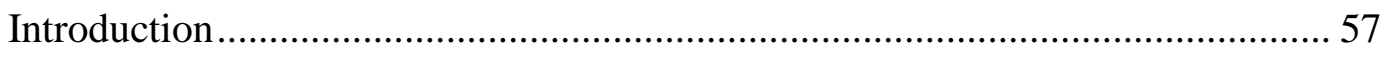

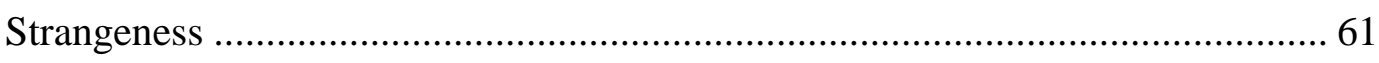

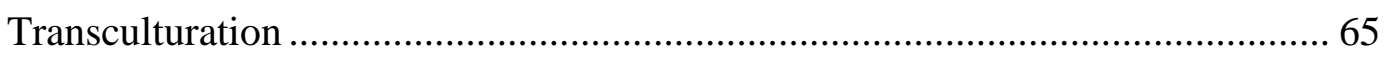

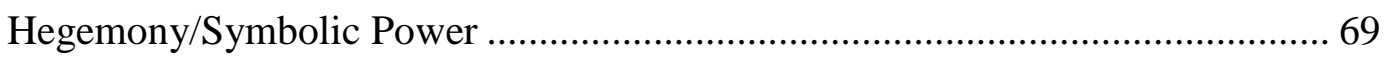

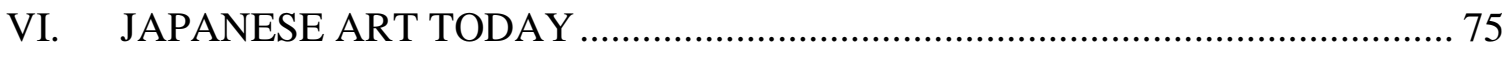

Modern Reception of Chiyo-ni and Yukinobu .................................................. 75

Contrasting Chiyo-ni and Yukinobu in Galleries Today .................................... 76

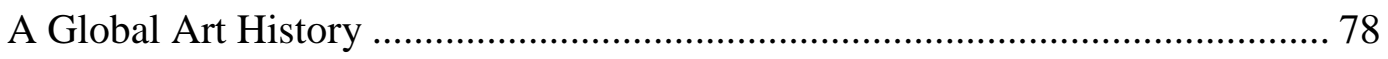

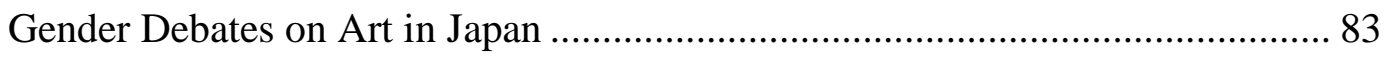

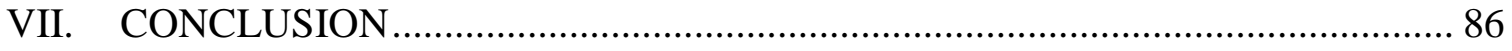




\section{LIST OF TABLES}

$\begin{array}{lll}\text { TABLE } & \text { PAGE }\end{array}$

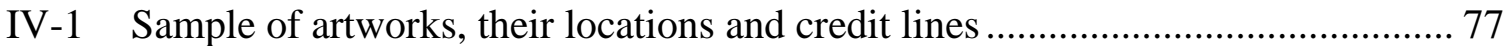




\section{LIST OF FIGURES}

FIGURE

PAGE

II-1 Kiyohara Yukinobu. "Yang Guifei." 17th century, Museum of Fine Arts, Boston. 8

II-2 Kiyohara Yukinobu. "Monju on a Lion." 17th century, Minneapolis Institute of Art, Minneapolis.

II-3 Kiyohara Yukinobu. "Botan Zu.” 17th century, Museum of Fine Arts, Boston. . 12

II-4 Toyokuni, Tanihiko Yanagatei and Utagawa Kuniyoshi. "Kokin mei fuden." 1863, National Diet Library, Tokyo.

II-5 Utagawa Kuniyoshi, “Chiyo-jo.” 1843-7, Museum of Fine Arts, Springfield, Massachusetts.

II-6 Fukuda Chiyo-ni and Karyo-ni, “Cherry Blossom Haiga.” Late $18^{\text {th }}$ century, Matto City Museum.

II-7 Fukuda Chiyo-ni and Yoho Naito, "Gourd Haiga." $18^{\text {th }}$ Century, Matto City Museum.

II-8 Fukuda Chiyo-ni, "Hinamatsuri haiga." $18^{\text {th }}$ century, Matto City Museum......... 21

IV-1 Kiyohara Yukinobu, "Yang Guifei Giving Her Hair Ornaments to a Messenger." Late 17th century, Museum of Fine Arts, Boston.

IV-2 Kiyohara Yukinobu, “Asparas (Flying Celestial).” Late $17^{\text {th }}$ century, Minneapolis Institute of Art.

IV-3 Fukuda Chiyo-ni and Toho Naito, "Morning Glory Haiga." $18^{\text {th }}$ century, Matto

City Museum.

IV-4 Fukuda Chiyo-ni, "Self portrait.” 1773, Nobutaka Aoki Collection, Matto City. 53 


\section{INTRODUCTION}

During the Heian and Edo periods, there were several notable examples of women artists and poets; however, it is the male artists and heads of art schools that are best known in the West. In her 1973 article "Why Have There Been No Great Women Artists?," Linda Nochlin acknowledges that the "white Western male" has been the de facto viewpoint of art history. She advocated that "A feminist critique of the discipline of art history is needed which can pierce cultural-ideological limitations, to reveal biases and inadequacies not merely in regard to the question of women artists, but in the formulation of the crucial questions of the discipline as a whole." (emphasis by quotation author) Thus, the goal of this research is not merely to select women artists whose works have been neglected here-to-fore. Instead, it will examine the social mechanisms and cultural changes occurring in Meiji-period Japan that shaped the art historical messaging and selection of works in museums, galleries and world expositions, and how these mechanisms subsequently effected Edo-period women artists' recognition. Since her publication, many debates on the generalities and universals of the "women problem" have occurred. Steps like the debates on women in art in Japan in the 1990s indicate a shift toward an understanding of the limitations inherent in the methodologies and traditions of art history. Art historians today are indebted to Nochlin and others for opening the conversation for constructive debate. This thesis is divided roughly chronologically, and further subdivided thematically. Below is a description of each chapter and subsection.

\footnotetext{
${ }^{1}$ Linda. Nochlin, "Why Have There Been No Great Women Artists?," in Women, Art and Power, 1988, $145-78$.
} 
The first chapter, "The Women Artists of Edo: Chiyo-ni and Yukinobu," introduces the main subjects of this thesis, their contributions and recognition, and provides visual analyses of several works. This analysis will serve as a framework for comparison and understanding of these artists and how their work was viewed, both inside and outside of Japan. Overall, treatment of the two artists varied due to their differing styles and how closely they aligned to Euro-American aesthetic principles. Comparing how both European and Japanese viewers might interpret these two artists illuminates major differences seen in the reception and display of their work. As we will see, many of Yukinobu's works exist in galleries in the United States, while the majority (if not all) of Chiyo-ni's haiku and haiga remain in Japan. Thus, the Western audience is exposed to the two artists in varying degrees. This thesis asserts that this is due, at least in part, to their relative appeal and conformity to Western preferences.

The second chapter, "Japanese Women Artists from Heian to AzuchiMomoyama" will set the backdrop for women in art by examining their roles in the history of Japanese art. During this period of nearly 1000 years, women had varying degrees of participation in the art world. The Heian period brought the renowned Genji monogatari (Tale of Genji) by Murasaki Shikubu, a woman author. The foremost artform of the time was waka poetry, which women were known for producing with prodigious, extemporaneous skill. However, such improvisational works were not often recorded and even less often included in royal anthologies of poetry of the time. The privilege to select worthy poetry always fell to men of high social standing. As such, it is difficult to know the true extent women were involved in the artform beyond anecdotal evidence from contemporary writings. The Kamakura to Azuchi-Momoyama section addresses reasons 
for the lack of female representation in artwork of these periods. Again, we see the man as the primary force for the canonization, even certification, of artworks worthy of appreciation and preservation.

The next chapter, "A Flourishing of Art in Edo" moves chronologically into the Edo period, sometimes called the Renaissance of Japanese art. As art is a product of society, the political and economic climate of Edo facilitated many new, innovative artforms. Taking a note from social scientists, this section discusses the role of art and how this role shaped cultural products and preferences of patrons. Next, it examines the work of two women artists of the period, Kiyohara Yukinobu and Fukuda Chiyo-ni, and their challenges and triumphs. In so doing, a picture of the contemporary reception and recognition of these artists is formed, which can be contrasted and compared with modern (Meiji period) treatment of these artists.

"Meiji Transformation of Art" introduces socio-cultural factors that effected Japan's renegotiation of the cultural value of art objects in Meiji period, which included strangeness, transculturation, and symbolic power. Strangeness is a term borrowed from W. Puck Brecher's book The Aesthetics of Strangeness which examines the art of the Edo period. Beyond a quality of artwork, though, strangeness was a tactic employed by the Japanese to emphasize the exotic and unique aspects of Japanese culture for EuroAmerican audiences who were relatively unfamiliar with the artwork to begin with. The second factor discussed is transculturation, coined by Fernando Ortiz when discussing the experience of native Cubans. During this time, Japan adopted Euro-American ideas and attitudes toward art, which were later adapted into institutional practices. For the first time, Japan's Ministry of Education attempted to construct a uniform art historical 
account that incorporated and related artworks through the centuries. This resulted in "winners and losers,", those who were included and those who were not. Further, transculturation manifested itself in new terms such as bijutsu (beautiful technique, or simply 'fine art') which lumped artworks into new categories. Combined with the strangeness of Edo-period artworks, such categorization led to problems. Finally, artworks are discussed in terms of symbolic power. Art of Japan has, for much of its history, centered around the desire to display one's wealth and power. In Meiji, this role of art was expanded to paint a picture of Japan as bunmei kaika (being civilized). These mottos and tactics of Meiji era art historians and curators led to few women artists being recognized and a mirror of "Western Great Masters."

The concluding chapter, "Japanese Art Today," discusses post-Meiji art critics' responses to Chiyo-ni and Yukinobu. It then contrasts the treatment and provenance of the two artists and proposes explanations for this difference. Finally, it addresses "big picture" scholarly debates about global art history and gender in and outside Japan. While much has changed since the beginning of the "modern" era in Japan, many of the debates and issues surrounding art in Japan have a basis in Meiji-period, which laid the foundation for a Western-style art history discipline and museums. As such, this research does not address pre- and post-War differences, which could be a topic on its own. Instead, it creates links between pre-modern and modern ways of thinking about art, and the influence of Euro-American ideals. Further, the goal is to link the particularities of the case studies presented to wider, more impactful issues that shape our understanding.

The goal of this thesis is to address the complex political, economic and cultural conditions that shaped the experience of women artists in Japanese history, and later 
resulted in their relative exclusion from galleries and art history accounts. While Japan certainly struggled with the role of women within art, the introduction of Euro-American concepts of fine art, avant-garde and the "Great Masters" exacerbated these extant divisions. Thus, both $u c h i$ (inside) and soto (outside) factors shaped the institutionalization of Japanese art, to the detriment of women artists like Chiyo-ni and Yukinobu. While art and gender debates have been occurring in Japan since the 1990s, this research seeks to expand the discourse of art history in global and local arenas. 


\section{THE WOMEN ARTISTS OF EDO: CHIYO-NI AND YUKINOBU}

Looking back on Edo period publications and biographies of the two artists, it is easy to see that they made an impact on the history of Japanese art and cleared a path for women as professional artists. Whether through accepting commissions, mentoring other female artists, or publishing their own works, Chiyo-ni and Yukinobu were pioneers in a previously male-dominated profession. Even with this much evidence of their success, it is still difficult to find biographies, descriptions and reproductions of their work in contemporary art historical publications. Thus, there is a difference between recognition of these artists during Edo period and Meiji-today.

This chapter will provide a basic understanding of these artists' lives and contributions, as well as visual analyses of relevant artworks from both a Japanese and European perspective. Because much of art history was written from the European point of view, understanding how aesthetic principles differed from those of the Japanese will demonstrate the reasoning behind selection of specific works for display and recognition in the canon of contemporary Japanese art history.

\section{Yukinobu}

Kiyohara Yukinobu was the daughter of an artist named Kusumi Morikage, and the niece of Kano Tan'yu, who was perhaps one of the best-known artists of the Edo period, known for his works at Nijo Castle Castle where he was commissioned by the Shogun, Iemitsu. ${ }^{2}$ As such, Yukinobu came from a pedigree of successful artists, was well educated, and trained as a painter. Yukinobu's work was well known enough that

\footnotetext{
${ }^{2}$ Karen M. Gerhart, The Eyes of Power : Art and Early Tokugawa Authority (Honolulu: University of Hawai'i Press, 1999), 1-3.
} 
Ihara Saikaku's The Life of an Amorous Woman includes a story where a courtesan commissions a work from Yukinobu. During Edo period, wealthy merchants and women from samurai families likely commissioned her to produce artworks for them.

Yukinobu was known for producing images of female heroines, and she produced several during her lifetime. Her interest in female heroines was likely began with her education. As a child, her father insisted that she receive the education typically reserved for boys headed for civil service. She read Japanese history and practiced painting with a teacher. This special attention would have given Yukinobu many opportunities to find heroes and heroines for subject matter, which fit well with Kano school's penchant for painting images of power and wealth. It also gave her the skills needed to pursue a career as a professional artist. While Yukinobu's artworks are relatively well catalogued and exist in galleries in and outside Japan, not much is written about her life in English. 


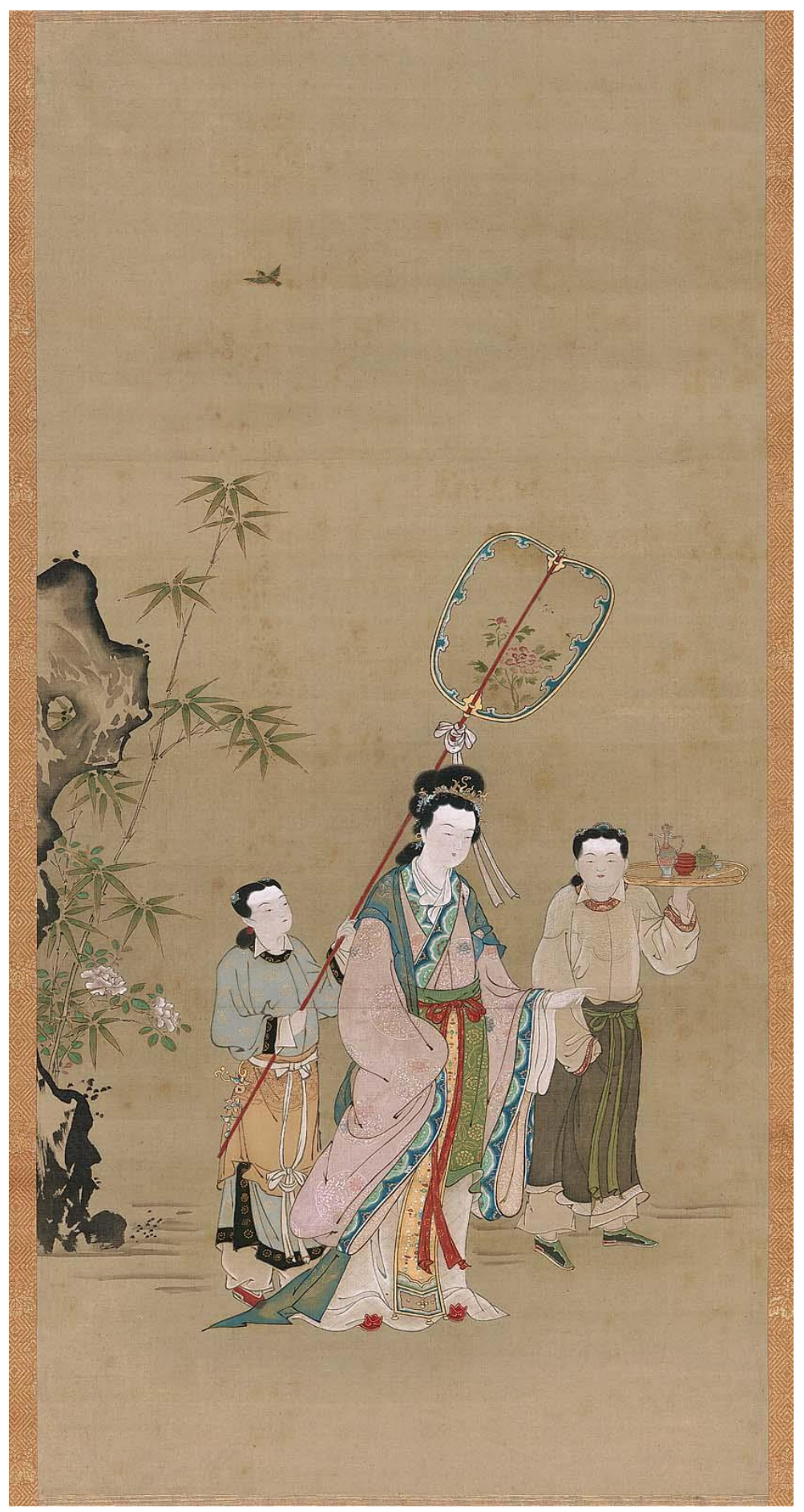

Figure II-1 Kiyohara Yukinobu. Yang Guifei. 17th century, Museum of Fine Arts, Boston. ${ }^{3}$

3 "Yang Guifei," Museum of Fine Arts, Boston, January 31, 2017,

https://www.mfa.org/collections/object/yang-guifei-26001. (One time fair usage). 
One heroine that Yukinobu painted several times was Yang Guifei. The choice of Guifei by the artist is a bold one - according to legends, this consort led to the downfall of a kingdom. Living in the Tang dynasty, she became the consort of the emperor. He eventually began neglecting his duties in favor of spending time with her, weakening the army. Guifei is considered one of the "Four Great Beauties" of ancient China. Figure II-1 above shows Guifei being attended to by servants, one holding a screen that shields Guifei from the sun while the other carries a tray of tea. A flourish of bamboo and chrysanthemum blossoms occupy the left side of the work.

From a Japanese perspective, this work shows the Chinese influence on Kano school's work and is very reminiscent of Song dynasty Chinese gongbi paintings that used delicate lines and vibrant colors. These works showed the artists' mastery of a fine haired brush, and variation in width was achieved through varying pressure. Here, the rendering of lines in her robes and face are very thin and precise. Small, ornate patterns show an array of rich fabrics and textures. Overall, the work is a testament to Yukinobu's masterful use of the brush. Beyond style, the work contains symbolism familiar to the Japanese viewer. Both the bamboo and chrysanthemum were revered for their resilience in the colder months. Their use in this work would have lent a sense of auspiciousness, and perhaps even alluded to the character of Yang Guifei.

From a European perspective, the subject matter and style of this work are complimentary. Delicate lines were equated with the feminine aspects of painting. The gently curved lines of the kimono sleeves and hemline allude to female curves beneath, even with the column shape created in the torso of the kimono. This sensuousness may have been viewed as an exotic, mysterious form of beauty. This attitude toward the 
Japanese woman is echoed in writings by French romance writer Pierre Loti, who travelled to Japan in 1885 in search of an "exotic" wife. ${ }^{4}$ Thus, works like this one would have satisfied Europeans' Orientalist tendencies and preference for otherness.

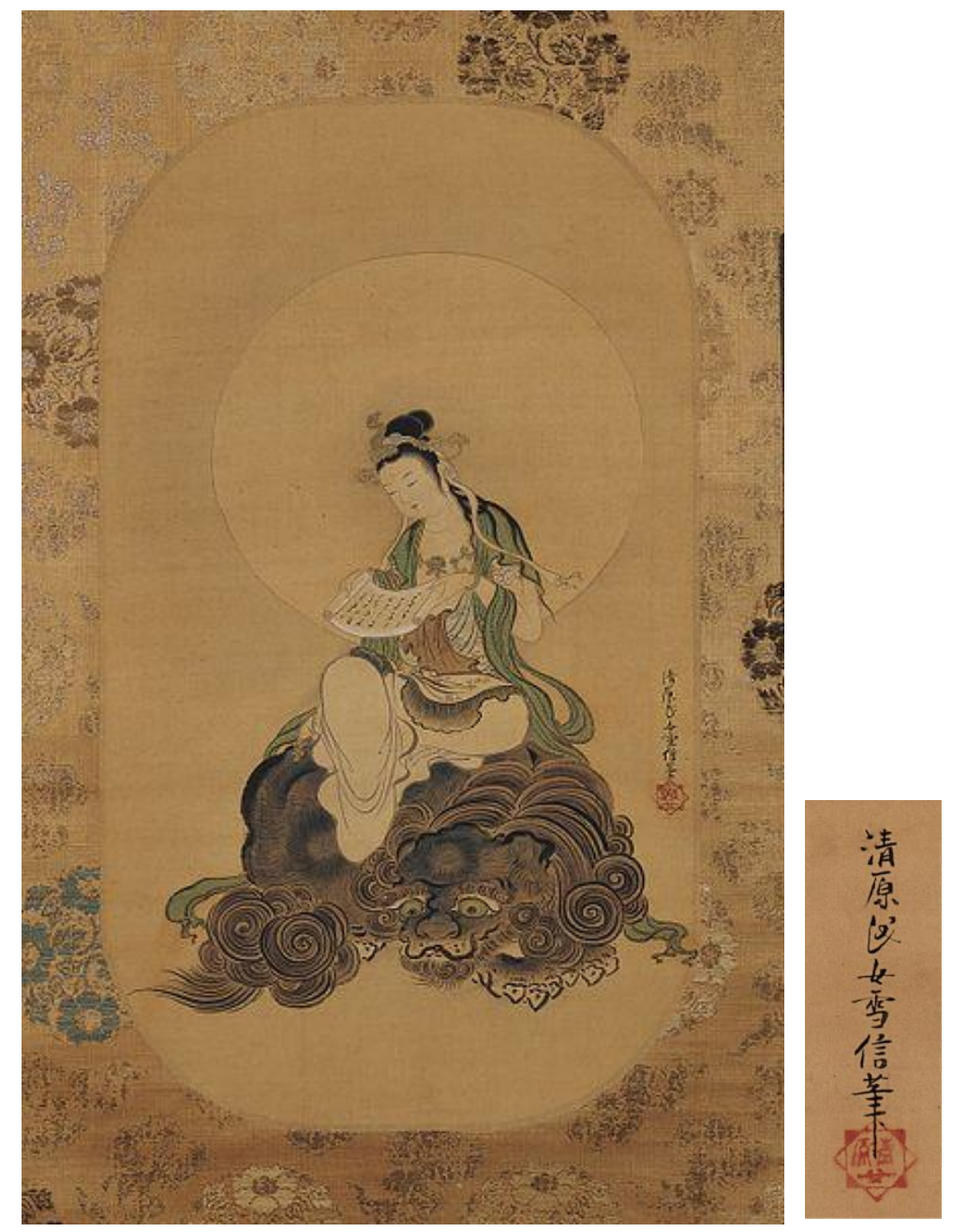

Figure II-2 Kiyohara Yukinobu. Monju on a Lion. 17th century, Minneapolis Institute of Art, Minneapolis. ${ }^{5}$

\footnotetext{
${ }^{4}$ Donald Richie, The Honorable Visitors (New York; Tokyo: ICG Muse, 2001), 64-65.

${ }^{5}$ Kiyohara Yukinobu Japanese, 1643 - 1682 and Kiyohara Yukinobu, Monju on a Lion, second half 17th century, Hanging scroll; Ink and color on silk, Height: 24 in $(60.9 \mathrm{~cm})$; Width: 14.1 in $(35.8 \mathrm{~cm})$ (image), second half 17th century, Minneapolis Institute of Art,
} 
Figure II-2 above, titled "Monju and the Lion," is owned by the Mary GriggsBurke collection. Yukinobu included a signature that read "Painted by the Woman of the Kiyohara Clan, Yukinobu.” Her seal reads Kiyohara-jo (Kiyohara woman). Yukinobu did not attempt to hide her gender, and it fact emblazoned most of her works with such a signature. Even so, she was a prolific artist who produced many works during her lifetime, including "Monju and the Lion."

The lion upon which the hero sits is an auspicious symbol of power, nobility and luck. The rough triangle created by the two sides of the lion and Monju's head at the top create a roughly triangular composition that is only slightly asymmetrical, a composition that was thought to mimic nature. The nimbus, or halo, around the head and the open scroll indicate Monju's enlightenment. This work may have originally been commissioned by a Buddhist patron who sought to accumulate merit, or as a symbol of some accomplishment or triumph. Unfortunately, there are no extant records of the provenance of this work.

From a Western point of view, the line use would appeal to a Western audience due both to its delicacy and the variation in the line weight and quality. This can be seen especially in the thick, thin and spiraling lines within the lion, the soft waving lines of Monju's robes, and the wispy, blurred lines used to render his hair. The choice of a gold toned paper with accents of white and black was a technique employed by many artists in the history of Western art, including Leonardo Da Vinci. The use of the halo surrounding the head is reminiscent of Byzantine artworks of the medieval period, and even the

https://commons.wikimedia.org/wiki/File:KiyoharaYukinobu_MonjuOnALion_MIA_L20153371.jpg. (One time fair use). 
downturned, three-quarters view of the face was seen in those times as well. Thus, a Western viewer could easily make the connection between these works and those of the Medieval or Renaissance period in Europe. While this work was surely distinct from works in Europe of the time, it could be easily fit into a Euro-centric model of painting.

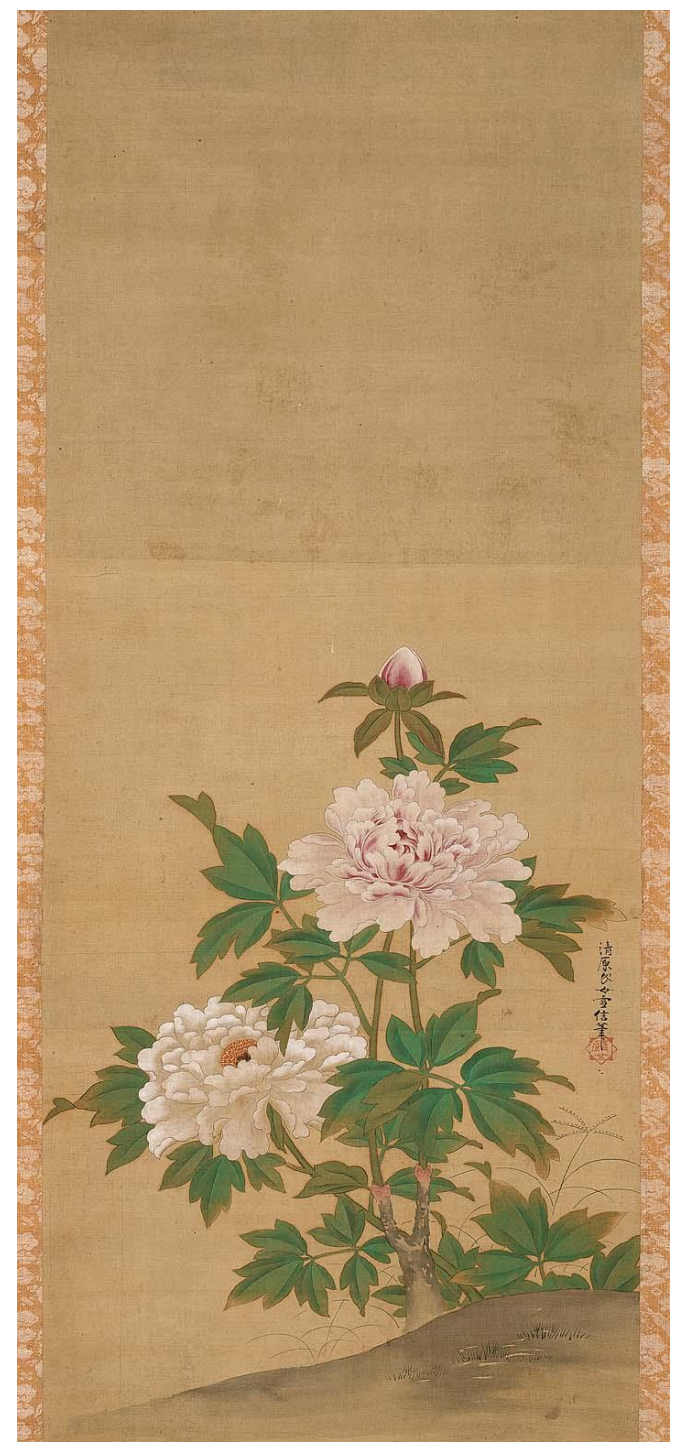

Figure II-3 Kiyohara Yukinobu. Botan $Z u$. 17th century, Museum of Fine Arts, Boston. ${ }^{6}$

6 “Peony," Museum of Fine Arts, Boston, May 29, 2018, https://www.mfa.org/collections/object/peony26006. (One time fair use). 
Figure II-3 is a work called 牡丹図 botan-zu (Peony drawing), which shows the peony in various stages of its life. Near the top is a bud, the center shows the pale pink bloom of the mature flower, and the bottom left shows a pollinated flower, having lost its color and ready to spread its seeds before withering. As with Yukinobu's other works, it is stamped with her name and uses the traditional gold background. Colored outlines of brown and grey were used, rather than black, and add to the delicacy of the linework. Careful shading was applied which shows no brushstrokes, giving the work an almost scientific feeling.

In Japan, the subject matter of this work, the botan (peony), would have had a symbolic significance for the viewer. Botan was called "the king of flowers" (花王) in China and was thought to represent fortune, nobility and femininity. ${ }^{7}$ Thus, this work would fall into a category of auspicious images popularized during the Edo period, which will be discussed in greater depth in the Edo chapter. Further, the barren ground on which the botan grows seems to allude to winter; some botan are able to bloom during the colder months and are thus revered by the Japanese for their resilience.

From a European perspective, this work is a faithful representation of life, in this case flowers. The West has had a long tradition of equating artistic value with beauty, and flowers are perhaps the quintessential example. The gradual shading used seems to suggest depth within the flowers and leaves, creating an illusion that the work almost "pops out" of the page. While it does not follow the rules of scientific perspective, that is, there are no objects in the back drawn smaller or vaguer in the distance, there is a sense

\footnotetext{
${ }^{7}$ Merrily Baird, Symbols of Japan: Thematic Motifs in Art and Design (New York: Rizzoli, 2001), 60.
} 
of space not present in some of the works that will be examined later. These aspects combine in the work to produce something that would have great appeal for Western viewers.

Chiyo-ni

Fukuda Chiyo-ni (1703-1775) was the daughter of a scrollmaker, and is best known as a haiku poet. So well known, in fact, that she was featured in numerous publications of artists, adding further authenticity and value to her work. These books included "Kokin haikai jokasen (Women haikai poets of modern and ancient times) [...] and Mikawa komachi, published by one of Bashō's disciples in 1702, which included one hundred haiku of women of the time." A collection of Chiyo-ni's verses, called Chiyo-ni Kushu, was also published during her lifetime, which was not common among Edo period artists. These written records of Chiyo-ni's works and the inclusion of her portrait in them shows the Japanese attitude that she is someone worthy of recognition.

Chiyo-ni was also known for her correspondance and mentorship of other Edoperiod haiku and haiga artists. One close friend and female haiku writer of the same circle, Suejo, corresponded frequently with Chiyo-ni. Nearly 40 letters recording their interactions exist today. Acting as a mentor to Suejo and other female artists ensconced her within the wider hierarchy of her field and meant her contributions went beyond her own art.

Chiyo-ni may be the most famous female haiku poet in Japan. However, little has been written about her and few English translations of her work exist. Patricia Donegan's Chiyo-ni: Woman Haiku Master, published in 1998, is the first collection of Chiyo-ni's work in English. This is interesting since a collection of Chiyo-ni's work was published 
during her lifetime. Ironically, until Donegan's book, Chiyo-ni's haiku had been published in some anthologies but never as a standalone collection that focused on one artist. Such neglect is not uncommon among women artists of Japan, and later chapters will address the myriad factors that cause this phenomenon.

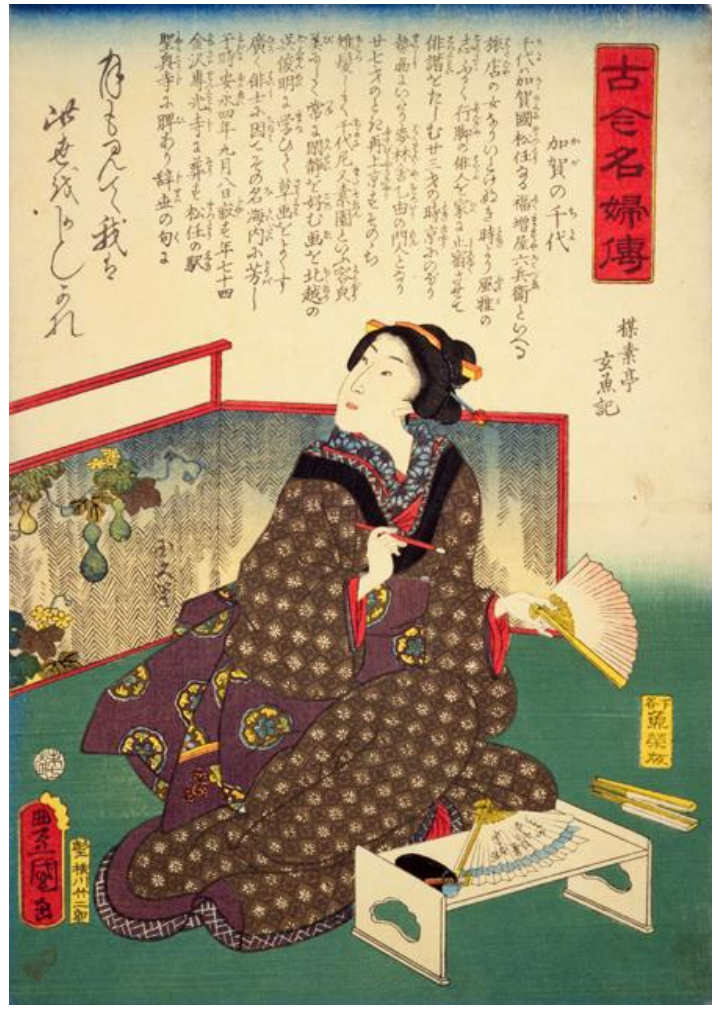

Figure II-4 Toyokuni, Tanihiko Yanagatei and Utagawa Kuniyoshi. Kokin mei fuden 1863, National Diet Library, Tokyo. ${ }^{8}$

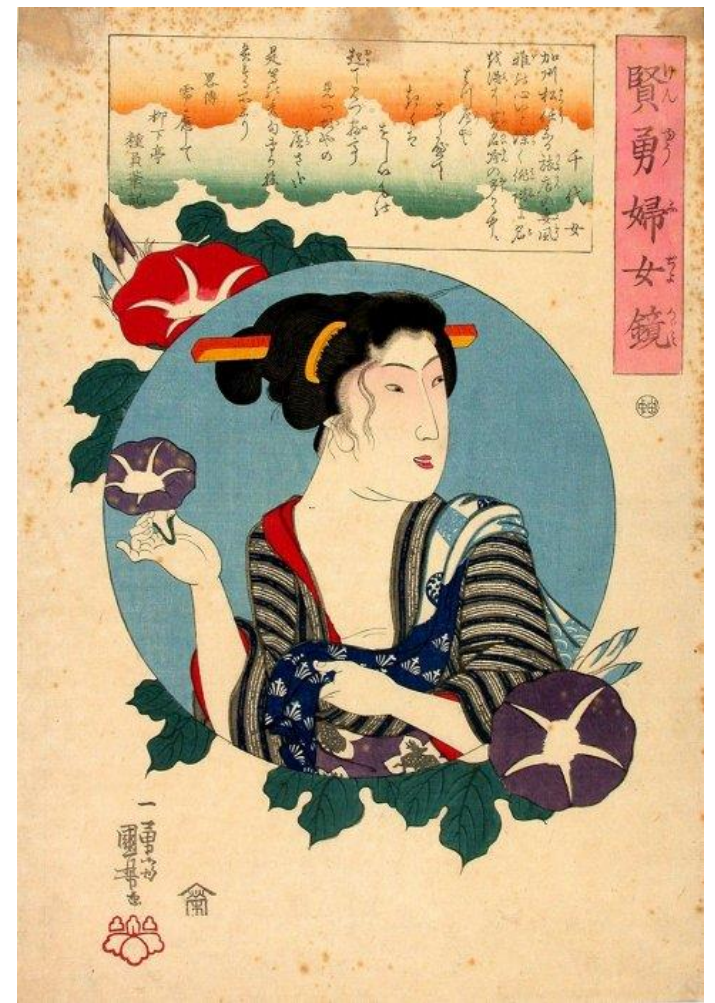

Figure II-5 Utagawa Kuniyoshi, Chiyo-jo. 18437, Museum of Fine Arts, Springfield, Massachusetts. $^{9}$

In the Late Edo period, Ryūtei Tanehiko (1783-1842) wrote 古今名婦伝, a book

containing a portrait and biography of Chiyo-ni. Figure II-4, taken from the work, shows

8 第三版, 日本大百科全書 (ニッポニカ), 世界大百科事典内言及ブリタニカ国際大百科事典 小項目事典, “千代女(ちょじ ょ)とは,” コトバンク, accessed May 8, 2018,

https://kotobank.jp/word/\%E5\%8D\%83\%E4\%BB\%A3\%E5\%A5\%B3-98376. (One time fair use).

9 “Kuniyoshi Project," accessed May 14, 2018, http://www.kuniyoshiproject.com/Mirror\%20of\%20Women\%20of\%20Wisdom\%20and\%20Courage.htm. (One time fair use). 
Chiyo-ni looking contemplative, brush in hand, and hard at work on a fan. This likely represents the commission that Chiyo-ni received from the Maeda daimyo for a set of fans that would be given to a Korean delegation. According to the Chiyo-jo Haiku Museum website, "In 1763, she was chosen to prepare the official gift presented to the Korean Delegation representing their nation. She crafted and delivered the 21 artworks based on her twenty-one haiku, for this honorable purpose. In fact, we can say that Chiyo-Jo was a forerunner, who played the role of encouraging international cultural exchange." The care and detail that went into this Ukiyo-e block print and the calligraphed biography show the extent to which Ryūtei Tanehiko respected her, and her selection in such an important commission shows her prominence at that point in her life.

The portrait on the right of Figure II-5 is Utagawa Kuniyoshi's Chiyo-jo from another collection of biographies. In this image, Chiyo-ni poses with the flower she popularized - the morning glory. She is surrounded by a ring of morning glories and holding one in her hand preciously. She appears in a loosely fitting kimono, her hand holding it closed around her for modesty. Like the first portrait, Chiyo-ni's head is turned to the side and gazing off in a contemplative expression. The rendering is similar in style with an elongated face, prominent chin, delicate facial features and ornately patterned robes. The image, again, is accompanied by a brief biography of Chiyo-ni.

Despite their recognition during the Edo period, neither Yukinobu nor Chiyo-ni are represented much in galleries in Japan or the West. However, the treatment of their works was not uniform. Overall, more works by Yukinobu are housed in the United States, while the majority of Chiyo-ni's haiga are housed by the Matto City Museum and the Chiyo-jo Haiku Museum in Matto, Japan. As we will see, European art critics shaped 
the perception of Japanese art, judging it by existing criterion. Due to this, some artists were elevated while others were ignored. Further, Japanese conflation of "modern" with "Western" meant that they quickly attempted to conform to European models of art history and aesthetic sensibilities. This may be why some calligraphic works, previously respected in Japan, were found wrapping the pottery and utensils sent to France and other countries during the Meiji period.

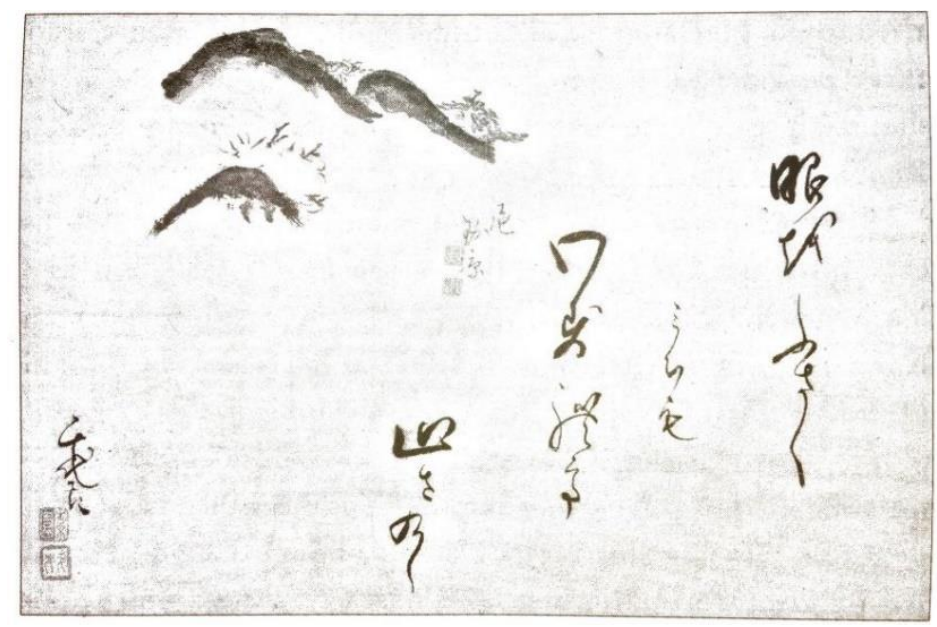

Figure II-6 Fukuda Chiyo-ni and Karyo-ni, Cherry Blossom Haiga. Late $18^{\text {th }}$ century, Matto City Museum. ${ }^{10}$

me o fusagu

michi mo wasurete

yama-zakura eyes oblivious

to the path

mountain cherry blossoms

Figure II-6 shows an example of a collaboration with another female artist,

Karyo-ni. This work is representative of Chiyo-ni's aesthetic. Lines of calligraphy run roughly parallel, but the beginning of each line is staggered, creating a kind of stream-ofconsciousness expression. The brushwork on the calligraphy is free-flowing, with the

${ }^{10}$ Patricia Donegan et al., Chiyo-Ni: Woman Haiku Master, 1st ed. (Boston, MA: Tuttle Publishing, 1998), 52. (One time fair use). 
brush only being lifted to designate separate characters. Within characters, we see thin strokes where the brush was not completely lifted from the page. At the end of two of the lines, the stroke trails off below the end of the character, as if lingering on the thought for a moment longer. The illustration in the upper left shows a simple rendering of mountain peaks in thick, deep strokes. The cherry blossoms are alluded to by smaller lines that jut out from the mountaintop. To the Japanese, this monochromatic, freeform work is consistent with artworks favored by Zen Buddhism. In this case, the calligraphy is part of the art and not merely writing. Thus, the writer is important, and the writing is the evidence of a moment of contemplation. The use of the cherry blossom would make this work seasonally appropriate for a Spring tea room.

From a European perspective, such a work would have been problematic. Rather than render the mountains as they are, the work shows a level of abstraction that Europeans would not have been accustomed to until it was popularized in the 1910s. Additionally, the West had no equivalent tradition of producing standalone calligraphic works with illustrations. The closest analogue would likely be illuminated manuscripts, but even those were bound into a book of many illustrations and calligraphed pages rather than being framed/hung individually. Thus, this work would have represented a problem with categorization, and the rendering could have been seen as a "failed" attempt at showing depth of field and perspective by some European viewers. 


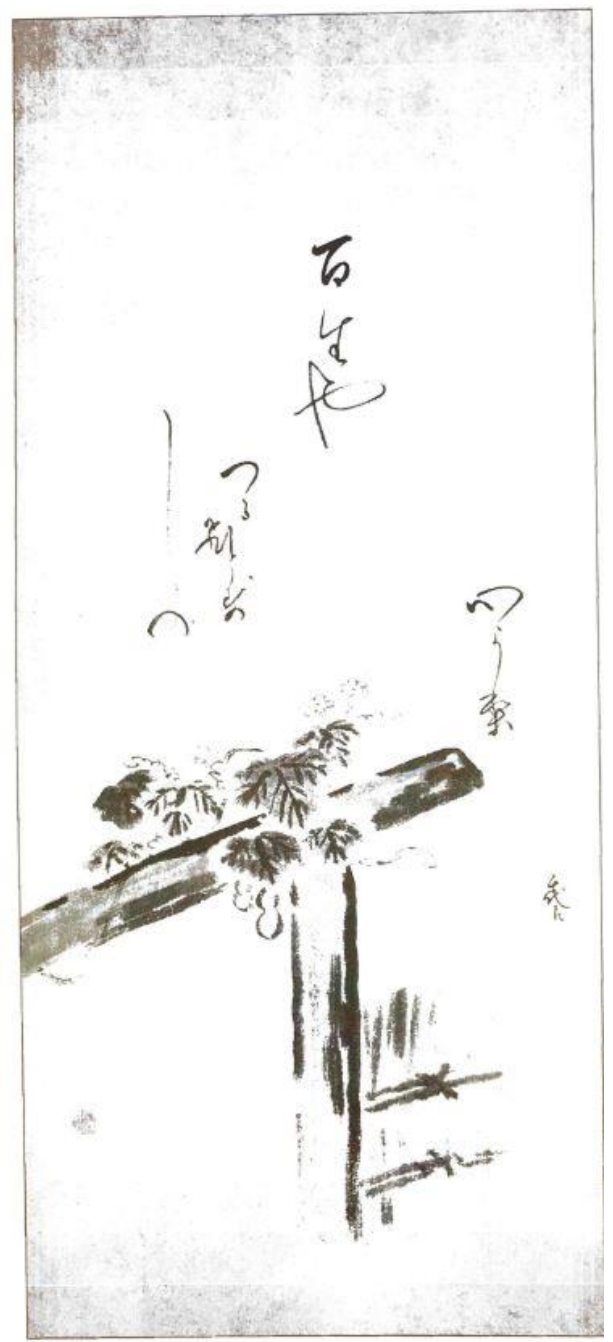

Figure II-7 Fukuda Chiyo-ni and Yoho Naito, Gourd Haiga. $18^{\text {th }}$ Century, Matto City Museum. ${ }^{11}$

$\begin{array}{ll}\text { byakunari ya } & \text { a hundred gourds } \\ \text { tsuru bitosuji no } & \text { from the heart } \\ \text { kokoro yori } & \text { of one vine }\end{array}$

Figure II-7, Chiyo-ni's gourd haiga, shows a fence post, likely made of bamboo, with a vine and leaves winding around it. The Japanese character for one hundred, byaku, is placed at the top middle of the composition and written with thicker strokes. Again, we see the free flowing "grass style" calligraphy. For the rendering, the fence is done with a

${ }^{11}$ Donegan et al., 183. (One time fair use). 
heavily loaded brush. This allows the artist to create each stroke only once, in a continuous motion. It also allows the ink to absorb into the paper, creating wider, blurred or fuzzy lines. The artist has also used washes of ink, where much more water was used, to create shades of gray within the fence and leaves. White spaces are left around each leaf to keep everything from bleeding together and losing definition. Like the last work, more emphasis is placed on the brushstrokes than faithful rendering of objects. The borders and shading used are thick and choppy with no transitional shades as one would see on a cylindrical shape. The work is also more heavily weighted on the left side, creating a feeling of asymmetry.

Europeans would likely have admired the composition of this work. Though the focal point is placed in the center of the page, the most simplistic composition, the stark diagonal lines of the fence posts create interest and break up an otherwise commonplace configuration. Beyond composition, though, the work does not adhere to ideas about paintings that faithfully represent the natural world. In real life, outlines do not exist but are instead shown through the contrast of edges. Thus, the heavy brushstrokes along the edge of the fence may have been perceived as crude or sketchy. This would have contributed to Europeans' assessment of the calligraphic works as "drawings" rather than "paintings" since the large-scale oil paintings they were used to seeing used color, value, and gradual shading to show objects as realistically as possible. Thus, the judgement of these works placed them outside the realm of Western painting by default rather than through careful examination of their merit. 


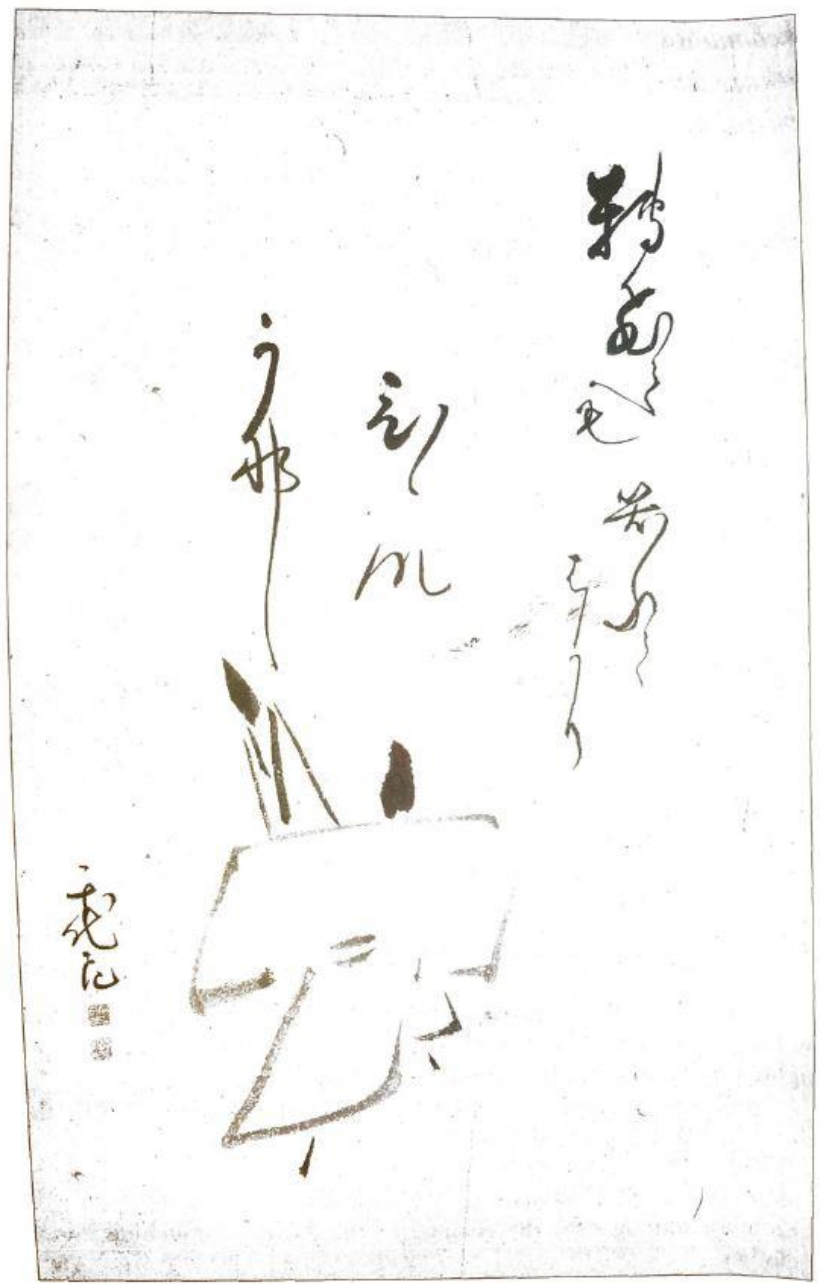

Figure II-8 Fukuda Chiyo-ni, Hinamatsuri haiga. $18^{\text {th }}$ century, Matto City Museum. ${ }^{12}$

$\begin{array}{ll}\text { korobite mo } & \text { Even falling down } \\ \text { warōte bakari } & \text { it still smiles } \\ \text { hi-i-na kana } & \text { the festival doll }\end{array}$

Figure II-8 is a depiction of a doll from the Hinamatsuri festival in Japan where many parents or grandparents put out a display of dolls that are thought to bring good luck and health to the girls in their family. These dolls are often placed on a stair-like platform in rows. In this case, we must imagine that one of the dolls was knocked from

${ }^{12}$ Donegan et al., 116. (One time fair use). 
its resting place and fell. The words of the haiku, then, are both beautiful and tragic - the doll falls but is still smiling. One can easily see the moralistic undertone expressed through an inanimate doll. Chiyo-ni is known for using such metaphors of everyday objects to show a deeper meaning through contemplation of their contradictions or unique qualities.

From a Western perspective, this work follows the rules for "good" composition specifically the rule of thirds, i.e. the focal point, in this case the hina doll, is positioned one-third of the paper's total width from to bottom and left edge. This is thought to be a more interesting composition. As a work created later in Chiyo-ni's life, there is a great deal of variation in line weight within the calligraphy, from very thick to very thin. We also see the long, trailing line endings as in Figure II-6. The figure of the doll is an abstract representation of the figure, and it is difficult to discern whether the doll is facing toward or away from the viewer. This ambiguous image may have been unsettling or primitive-looking to some seeing it for the first time. 


\section{JAPANESE WOMEN ARTISTS FROM HEIAN TO AZUCHI-MOMOYAMA}

Heian period (794-1185)

The Heian period in Japan is often considered a golden age of art and culture. With relative stability under the rule of the Fujiwara shogunate, Heian citizens, especially among the noble class, were free to pursue artistic ventures. Further, women played a significant role in shaping the art of Heian. This was due, at least in part, to the perception that cultured women should have "both the appreciation of painting and the ability to paint"13 as a prerequisite of marriage. In a time where status at court defined the lives of nobles, having a daughter marry into a prestigious family and find a place at court was an end goal. Japanese noblemen would spare no expense to "enhance their charms" ${ }^{\prime 14}$ As a result, many noblewomen were not only well read and adept at writing kana, but also able to paint and enjoyed paintings. Chiyo-ni and Yukinobu would have benefited from this perception of women artists as cultured, and we see that influence in their childhoods.

Much has been written about the literary contributions of women; the two most notable being Sei Shonagon's Makura no sohi (Pillow book) and Murasaki Shikibu's Genji monogatari (The Tale of Genji). ${ }^{15}$ But there were many lesser-known noblewomen who produced diaries that also served as autobiographies. The term diary is a bit misleading here, since they were "artistic narratives of female self-representation rather

\footnotetext{
${ }^{13}$ Marsha Smith Weidner, Flowering in the Shadows : Women in the History of Chinese and Japanese Painting (Honolulu: University of Hawaii Press, 1990), 161.

${ }^{14}$ Weidner, Flowering in the Shadows, 159.

${ }^{15}$ Weidner, Flowering in the Shadows, 160.
} 
than the unstructured series of disparate entries commonly understood by the term 'diary." "16 The tendency to write diaries was, at least in part, motivated by a desire to make up for their lack of visibility compared to men. In waka poetry, men wrote about the ability of women to produce poetry in an improvisational manner at an uta-awase (poem competition) event. ${ }^{17}$ Men, by contrast, were recognized in publications and for their ability to write poetry after careful contemplation. The decision to relegate women to the uta-awase limited women to roles as participants and did not allow them to have formative effects on publications of works. Unlike these unsung artists of Heian, Yukinobu and Chiyo-ni's works were published during their lifetime.

While, the talents of women in the uta-awase were recognized, "no woman poet in the Heian period, however gifted, was invited to serve as the judge of a poetry contest or to compile a royal anthology. Nor do any texts survive-with the exception of Yasusuke $\overline{\mathrm{O}}$ no Haha's chinjō- that could be regarded as a poetics by a Heian woman. These roles had always been the preserve of male poets, and for the patrilineally organized poetic houses they were critical in enhancing and consolidating their positions." ${ }^{\prime 18}$ Thus, it fell upon men to construct the canon of official poetry that would be preserved and recognized. Due to this, it is difficult to know the full extent of the contributions of Heian women. However, we know from contemporary accounts that women did interact with the poets who were later published in royal anthologies.

\footnotetext{
${ }^{16}$ Rebecca L. Copeland and Esperanza. Ramirez-Christensen, Father-Daughter Plot : Japanese Literary Women and the Law of the Father (University of Hawaii Press, 2001), 49.

${ }^{17}$ R. Bundy, "Gendering the Court Woman Poet: Pedigree and Portrayal in Fukuro Zoshi," Monumenta Nipponica 67, no. 2 (2012): 209.

${ }^{18}$ Ibid.
} 
Due to their exclusion from anthologies, women took it upon themselves to document their life experiences. They selected poetry to tell such stories, since it was thought to be "a universal expression of the heart-mind"19 and thus communicated the sincerity of their experiences. One explanation for the desire to construct autobiographies is "the loss of power and status" suffered by women of this period. Political reforms "instituted the patrilineal order by identifying the male as head of household (koshu) in the official registers." 20 This limited women's claim to property, and the patriarchal family became the basic family unit. Further, men were able to practice polygamy while women were not. Also, women were excluded from holding public office, resulting in their utter dependency on men.

Women's lack of power and recognition in anthologies make it is hard to find documentation of their contributions, especially as painters. Like with literature, efforts were made to distinguish women artists from their male counterparts. Terms such as onna-e (woman painting) came into use to describe a distinctly feminine expression of art, though it is difficult to find such a connection in finished products. Such terms were called into question even during Heian times. Whether there is truly a feminine style of painting is a subject of debate, though often onna-e was used to describe courtly illustrations of literary works such as Genji monogatari. However, it is possible that men

\footnotetext{
${ }^{19}$ Copeland and Ramirez-Christensen, Father-Daughter Plot : Japanese Literary Women and the Law of the Father, 59.

${ }^{20}$ Copeland and Ramirez-Christensen, Father-Daughter Plot, 51.
} 
produced onna-e and women produced otoko-e (men's painting), so that the names refer more to a style than the gender of the artist. ${ }^{21}$

Though there may not have been a women's style of painting, we do know that women produced paintings. In fact, the skill was thought to be a requirement of "cultivated aristocratic women or lady-in-waiting"22 New painting genres were developed that complemented the literary tradition of women, such as uta-e (poem picture) and monogatari-e (tale picture). These paintings, which accompanied written works, served to illustrate the narrative. Further, Genji monogatari has several mentions of women engaging in painting. These women were limited to producing works thought proper for noblewomen, since most secular painting of the time was done by professional artists, who were almost always men. However, there are a few notable exceptions to this. ${ }^{23}$ In summary, while the Heian period was an exciting time to be an artist and poet in Heian period, women found it difficult to find their place within the professional art world. While having a great woman artist/author as a mother or grandmother guaranteed one a spot at poetry gatherings, women played an ancillary role due to their presumed ability to produce poetry extemporaneously. Men of this era who were charged with producing collections of poetry for the emperor solidified their position by excluding the female poet. Thus, the diary literature and poetry produced by women of this time can be understood as a cry for recognition in an era of repression and limited freedoms. While

\footnotetext{
${ }^{21}$ Weidner, Flowering in the Shadows : Women in the History of Chinese and Japanese Painting, 232.

${ }^{22}$ Weidner, Flowering in the Shadows, 160.

${ }^{23}$ Weidner, Flowering in the Shadows, 161.
} 
there are a few notable examples of professional women artists and poets of the time, to say that women had an easy time breaking through these barriers would be remiss. These conditions seem to mirror contemporary reception of women artists of the Edo period as well, with more recognition at the time of creation that wanes, with the males being canonized.

\section{Kamakura to Azuchi-Momoyama period (1185-1600)}

In Heian, there were examples of successful female artists. Art was a charming pastime of noble women and was considered an investment for marriage. From Kamakura to Azuchi-Momoyama, though, teaching women to paint fell out of practice in more frugal, militaristic times. During this timeframe of around 400 years, which is sometimes called medieval or feudal Japan, there was a lack of participation and recognition of women in the arts. There were several reasons for this, including daimyo culture, Buddhist patronage, royal anthologies that continued to exclude women, and tea ceremony aesthetics.

After the dissolution of the centralized government of the Heian period, Japan was ruled by the bafuku (tent government), a militaristic, feudal administration. The power dynamics of this era meant that aesthetic sensibilities were no longer the sole property of the nobility. In fact, "the warrior class favored artists who treated their subjects with a direct honesty and virile energy that matched their own." ${ }^{24}$ Poetic forms such as waka, for which women poets were known, became less popular, and realism was favored. This was the beginning of a style of art of the daimyo, "a synergy of warrior

\footnotetext{
24 "Kamakura and Nanbokucho Periods (1185-1392)," The Metropolitan Museum of Art, www.metmuseum.org/toah/hd/kana/hd_kana.htm, (March 23, 2018)
} 
traditions (bu) and civilian arts (bun). ${ }^{, 25}$ This resulted in the creation of new modes of artistic expression to suit the tastes of high ranking generals. These works were almost exclusively created by men, who were thought to have a higher capacity for objectivity than women.

The political climate of Kamakura also influenced the expansion of Buddhism. Conflict among clans, economic hardship and disputes over imperial succession led strained the loyalty of the already struggling samurai. Many sculptural works showed religious imagery combined with military power, such as images of the Juni Shinsho (Twelve Divine Generals). These stressful times led to the expansion of Buddhism to the common people. This led to patrons of art whose contributions held "the expectation of accruing merit toward salvation." 26 This necessitated the commission of works by priests and other religious people. Where women factored into Buddhist practices of this time is beyond the scope of this thesis, though it is safe to assume that most Buddhists who were commissioned to create artworks were men.

Leaders of Kamakura continued the Heian tradition of royal anthologies of poetry. In fact, it became more institutionalized when "the retired emperor Go-Toba (r. 1183-98) established the Bureau of Poetry, the Wakadokoro, and commissioned the compilation of the twenty-volume anthology Shin kokin wakashū (New Collection of Poems Ancient and

\footnotetext{
${ }^{25}$ Yoshiaki Shimizu, Japan: The Shaping of Daimyo Culture 1185-1868 (Washington, D.C.: National Gallery of Art, 1988), 5.

${ }^{26}$ Ibid, 69
} 
Modern)." 27 There are many examples of calligraphy and poetry preserved from this era. ${ }^{28}$ Despite these efforts, women are not mentioned in poetry accounts.

The Muromachi period is named for the shogun's headquarters, set up in region of Kyoto. The aesthetics of this period were heavily influenced by Chinese painting, "particularly the art of the Song and Yuan dynasties"29 This was likely due to an interest in reclusion which "express aspects of eremitism in that they often suggest or depict the rejection of the human realm." 30 Buddhism continued to be important to the art of this period, and "a new doctrine, Zen, was enthusiastically embraced by the military class" 31 While Zen was often seen as having "no need of scriptures, temples, icons, or the paraphernalia of religious institutions," 32 Zen practitioners brought with them aesthetic sensibilities from Chinese culture, specifically Chinese literati painting. ${ }^{33}$ Works that were simple, spontaneous, and expressed feelings and thoughts in monochrome ink conformed to Zen concepts and preferences. Further, traveling monks between China and

\footnotetext{
27 Ibid, 68.

${ }^{28}$ Shimizu, Japan: The Shaping of Daimyo Culture 1185-1868, 106-18.

${ }^{29}$ Murase, Burke, and Metropolitan Museum of Art, New York, "Bridge of Dreams : The Mary Griggs Burke Collection of Japanese Art," 125.

${ }^{30}$ Kendall H. Brown, The Politics of Reclusion : Painting and Power in Momoyama Japan (Honolulu: University of Hawai'i Press, 1997).

${ }^{31}$ Murase, Burke, and Metropolitan Museum of Art, New York, "Bridge of Dreams : The Mary Griggs Burke Collection of Japanese Art," 125.

${ }^{32}$ Murase, Burke, and Metropolitan Museum of Art, New York, 125.

${ }^{33}$ Shimizu, Japan: The Shaping of Daimyo Culture 1185-1868, 13.
} 
Japan led to exchange of culture and art, continuing the influence of Chinese painting in Japan. $^{34}$

The Azuchi-Momoyama period's aesthetic can be related directly to the aesthetics of cha-no-yu (tea ceremony). Women were not allowed to practice tea ceremony until much later, meaning that this aesthetic was exclusively promoted by male tea masters. Sen no Rikyu (1522-1591), the man often thought to be the grandfather of cha-no-yu, defined the principles and aesthetics of tea. Rikyu was the sole connoisseur and curator of all things tea, and the selection of utensils and hanging scrolls was carefully governed by his preferences. The tea master as cultural/aesthetic authority would be echoed by iemoto in later time periods.

Traditionally, objects were also judged based on their lineage. Until the $16^{\text {th }}$ century, rare Chinese objects were highly valued. Rikyu and others later shifted the aesthetic away from karamono (Chinese objects) to rustic, asymmetrical wabi. This choice to include Japanese wares with a "cold and withered" style that was more accessible to merchants and commoners allowed Hideyoshi, the leader of the time, to ingratiate himself to them and validate his rule. Through his conduct, "utensils became war prizes, small gatherings functioned as networking opportunities, and large gatherings marked triumphal military victories." ${ }^{35}$ Thus, the tea ceremony became a key social tool for the ruling class maintain power and legitimacy.

\footnotetext{
${ }^{34}$ Murase, Burke, and Metropolitan Museum of Art, New York, "Bridge of Dreams : The Mary Griggs Burke Collection of Japanese Art," 125.

${ }^{35}$ Kristin Surak, "From Selling Tea to Selling Japaneseness: Symbolic Power and the Nationalization of Cultural Practices," European Journal of Sociology 52, no. 02 (August 2011): 175-208, https://doi.org/10.1017/S0003975611000087.
} 
While Rikyu favored a wabi style, he was still commissioned by Hideyoshi to construct a solid gold tea room that suited Hideyoshi's ostentatious sensibilities. ${ }^{36}$ Yet even Rikyu used shiny black lacquerware. How, then, can the shiny be permitted into the grass hut of the tea room? In his essay titled "In Praise of Shadows," published in 1933, Jun'ichirō Tanizaki explains the anomaly of shiny objects in a Japanese home. He argues that gold and black lacquerware are not so glaring when lit by dim ambient light and candles, ${ }^{37}$ which would have been commonplace in homes/tearooms during Rikyu's time. The subtle glitter of the gold or the shimmer on the rim of the black lacquerware, rather than being glaring and obvious, offered subtle shifts in the light in momentary glimpses. When seen as a longing for light, the golden tearoom can be better reconciled with the taste for wabi-sabi; it certainly was a display of wealth and power, but in an aesthetic sense is not as anomalous as one might otherwise believe. This understanding of shadow and light is one way that lacquerware for natsume (tea caddy), sometimes inlaid with mother of pearl or gold, could keep their place next to the wabi style chawan (tea bowl).

Beyond the contrast of light and shadow, tea utensils are also chosen to contrast between each other. Jukō's famous words "a magnificent steed in a straw hut" exemplify this ideal of combining high and low, smooth and textured, soft and hard. Much of Japanese aesthetic can be understood in terms of these binaries, which have filtered in via Confucian and Daoist ideas about yin/yang, masculine/feminine, dark/light. Through balancing these two forces, harmony can be achieved for the guest and host.

\footnotetext{
36 Surak, "From Selling Tea to Selling Japaneseness," 2011.

37 Jun'ichirō Tanizaki et al., In Praise of Shadows (New Haven: Leete's Island Books, 1977).
} 
As we have seen, tea masters (iemoto) were at the heart of aesthetics and selection of cultural objects during the Azuchi-Momoyama period. As with selection of waka poetry in Heian period's royal anthologies, such a privilege was bestowed via patrilineal pedigree. Women were not allowed to perform the tea ceremony, and thus had no influence in shaping the aesthetics of this period. Further, there is little textual evidence of women painters and artists during this time. Due to cultural trends toward specific aesthetics (whether influenced by tea culture, Buddhism, or the daimyo) women were marginalized from public and private art until the Edo period. 


\section{A FLOURISHING OF ART IN EDO}

Introduction

The Edo period (1603-1868) in Japan, an era of political/economic stability and sakoku, ${ }^{38}$ was one of contradictions. On one hand, this period established a social hierarchy with strict gender roles and even proscriptions for proper dress. On the other, it saw the rise of the merchant class and popularity of a variety of artforms that appealed to the masses. Political stability, increased access to education, the growth of the merchant class and the appreciation of strangeness in the Edo period all contributed to a resurgence of female artists that had not been seen since the Heian period. Edo period also saw the first publications that included women artists, and the first examples of professional female artists who took commissions, rather than the more casual artistic endeavors that had been acceptable previously.

Two women artists of this era, Kiyohara Yukinobu (1643-1682) and Fukuda Chiyo-ni (1703-1775), made a name for themselves in the field of Japanese painting. They had very different backgrounds; Yukinobu was born and lived in Kyoto while Chiyo-ni grew up in rural Matto. Even so, they both received education in literature and art and were later mentored by a prominent disciple of an art school. Chiyo-ni's style, consistent with the Bashō school, creates a balance between image and haiku, often using a monochrome palette. Yukinobu, by contrast, uses delicate black linework, striking

\footnotetext{
${ }^{38}$ Sakoku was the policy implemented by Hideyoshi in response to the arrival of Portuguese, Spanish and English missionaries and merchants. Ports were closed to most foreign travelers, though Chinese and Dutch were still allowed at Kyushu. This policy is sometimes cited as the main reason for refinement and proliferation of arts in Edo Japan. However, the art of the Edo period (and even the intellectual thought) was highly influenced by Chinese thought and art.
} 
images, vibrant colors and even gold leaf to create visual impact. Both artists signed their works with their names and were included in contemporary publications that highlighted important artists and figures of Edo. Due to this, art historians conclude they were well known and successful during their lifetimes. This is especially noteworthy due to the strict roles women were relegated to, which will be discussed in greater detail in this chapter.

\section{The State of Society in Edo}

During the Edo period, conditions were favorable for a flourishing of the arts. With a relatively stable government and the growth of the merchant class, there was a boom in artistic production. Increased creativity, mostly in major urban areas, correlated with wealth and power of chonin (merchant and artisan) class. ${ }^{39}$ Writings of the time, like Yamaga Soko's Nihon Rinri Ihen (Japanese Ethics Disaster), describe the hierarchy as having samurai at the top with peasants, artisans, and merchants below them. The rationale used to explain this was "The samurai use their minds, the peasants and those below them use their muscles." Yamaga Soko feared the reversal of this hierarchy, arguing that it could lead to chaos in Japan. ${ }^{40}$

Unfortunately for Yamaga Soko, that is exactly what happened. Daimyo demanded high stipends and were increasingly defined by institutions rather than military power. ${ }^{41}$ While the samurai class was still considered to be at the top of the social

\footnotetext{
${ }^{39}$ Masao. Maruyama, Studies in Intellectual History of Tokugawa Japan. (Princeton: Princeton University Press, 2016), 116.

${ }^{40}$ Maruyama, Studies in Intellectual History of Tokugawa Japan, 9.

${ }^{41}$ Shimizu, Japan: The Shaping of Daimyo Culture 1185-1868, 31.
} 
hierarchy, they did not produce goods and relied on artisans and merchants. This led to a slow erosion of the established social order as chonin gained political and economic power. ${ }^{42}$ In reality, samurai were often beholden to chonin who produced or acquired the goods they consumed. Due to the gradual nature of the change, it did not result in large scale conflict or instability as Soko had predicted. Instead, it meant that education and wealth were accessible to more people and not just samurai.

The city of Edo became the cultural hub of Japan due, at least in part, to the sankin kotai system which required loyal daimyo to bring their wives and children to Edo every other year. Since the families and daimyo resided there for the purpose of serving and showing loyalty to the shogun, highly ritualized standards of dress and behavior developed. This resulted in a vital, metropolitan culture that shaped aesthetics and fashion and still does so today. ${ }^{43}$

In addition to political and socio-economic conditions being favorable to the production of art, education of girls became more commonplace, and led to increased opportunities for women artists, especially in poetry. Furthermore, the printing of books spread knowledge and ideas outside of urban centers and increased literacy. Along with this proliferation of knowledge came Neo-Confucian ideology, which was no longer just the domain of scholars but of the public. It was believed that the "Way" was based on the

\footnotetext{
${ }^{42}$ Maruyama, Studies in Intellectual History of Tokugawa Japan., 122-29.

${ }^{43}$ Shimizu, Japan: The Shaping of Daimyo Culture 1185-1868, 35.
} 
natural order of things, and the "truth of heaven and earth and nature." 44 This became the basis and impetus for education in Japan.

While some scholars are skeptical of the influence of Neo-Confucianism in Japan, the Edo period is one time where such influence is accepted as truth. During this time, "learning broke free of its previous reliance on religion and became independent." ${ }^{45} \mathrm{Neo}-$ Confucianism taught that women's place was in the home as mothers and wives. In "The Great Learning for Women," women are defined by the actions/thoughts of their husband and must follow his rule absolutely. The work is rife with proscriptions for proper expressions of filial piety. Not only does this work stress the importance of subordination to the man and his family, but also portrays women as naturally wild and vulgar. For this reason, women were often expected to stay in the home, away from men, due to their corrupting influence. ${ }^{46}$ Luckily, some women were able to escape these strict mandates on behavior through their artistic pedigrees or becoming nuns.

\section{The Role of Art}

Patrons of art in Edo "were highly informed observers who were well trained in interpreting complex visual iconography" and the "iconography was in turn crucial in defining the status of these individuals ${ }^{" 47}$ Imagery was chosen by artists for its ability to convey status and wealth. Further, the motifs served to maintain and reinforce the

\footnotetext{
${ }^{44}$ Maruyama, Studies in Intellectual History of Tokugawa Japan., 124-29.

${ }^{45}$ Maruyama, Studies in the Intellectual History of Tokugawa Japan, 189.

${ }^{46}$ Wm. Theodore de Bary et al., "Sources of Japanese Tradition," in Sources of Japanese Tradition, 2nd ed., vol. 1 (New York Chichester: Columbia University Press, 2001), 399-425.

${ }^{47}$ Karen M. Gerhart, "Eyes of Power : Art and Early Tokugawa Authority.," 2000, 30, http://public.eblib.com/choice/publicfullrecord.aspx?p=3413054.
} 
established hegemony. Some artists of the Kano school of painting were labeled oku-eshi 奥絵師 (official painters) and were required to come to the imperial castle six months out of the year to produce commissioned works. ${ }^{48}$ This led to Kano school having a certain authority over artworks and aesthetics. To this day, it is one of the best-known painting schools in Japan.

One example of the role of official patronage is the work of Kano Tan'yu (16021674) in the interior of Nijo Castle, the estate of the third shogun Iemitsu. The motif chosen, the pine tree, was an image long associated with longevity due to the tree's ability to stay green even during harsh winters. The matsu (pine tree) would have "elicited specific psychological responses from those receiving audiences in the Grand Audience Hall because the artist, Tan'yu, transformed this single motif, the pine tree, into a vigorous and impressive political message" In this way, Tan'yu was able to turn decorations into something that spoke to the power, wealth, and sophistication of the Shogun Iemitsu. Further, Tan'yu's choices “validated the presence of the newly appointed shogun, Tokugawa Iemitsu, in the capital and, by its grand size and sumptuous decoration, affirmed that he was an individual of decorum and exquisite taste- $\mathrm{a}$ man of sufficient pedigree to entertain an emperor." This meant that, beyond showing power and wealth, the artworks communicated sophistication and culture. The image of the pine, as well, became synonymous with the emperor himself. Thus, individuals viewing the pines would catch on to the message that the shogun is an extension of the emperor to serve the

\footnotetext{
${ }^{48}$ Ibid, 24.
} 
greater good..$^{49}$ This function of art, as symbolic power and legitimization of rule, was a central consideration of patrons of art during the Edo period.

While education and economic structures of Edo were modern by our standards, folk knowledge was still very much reflected in the art of the time. In many cases, images chosen were "omen images" meant "to drive away evil." 50 To give an image of a natural scene-especially containing dragons, lions, or perennial plants-was to wish the recipient good fortune and longevity and increased the value of the image. ${ }^{51}$ Such was the case with Kano Tan'yu's pine trees. These symbols constituted a visual vocabulary that was known not only in Japan, but in the East Asian region. ${ }^{52}$ This vocabulary of imagery constructed a framework in which artists operated.

Even in this formal structure of official artists and iconography, we see those artists who broke off from the norm and produced works that defied the established order. They did not do so for a political purpose, but merely to explore unfamiliar territory. The counterpart of "normal" is "strange," and some artists were labeled as such due to their choice of subject matter, being women, and other factors. Their strangeness was due, in part to their identities - as women, outcasts, or monks. But just as strange was the iconography they chose to focus on, which often did not follow the tradition of omen images.

\footnotetext{
${ }^{49}$ Gerhart, "Eyes of Power, " 1-3.

${ }^{50}$ Gerhart, "Eyes of Power," 17.

${ }^{51}$ Timon Screech, Obtaining Images : Art, Production and Display in Edo Japan (Honolulu: University of Hawai'i Press, 2012).

${ }^{52}$ Ibid, 40.
} 


\section{Strangeness in Edo}

Artists in Edo period had to rely on patrons to maintain their lifestyle and dedicate themselves to their chosen artistic path. Official patrons would often be rigid with their expectations, but more merchants became involved in patronage of the arts. Often, chonin patrons would be more open to creative expression and enjoyed artwork that was different or unusual. This resulted in many innovations in subject matter, if not in style. Art of Edo is often strange, that is, has a unique choice of subject matter and seemingly incoherent iconography that did not utilize the same visual vocabulary as more traditional works, or sometimes turned the paradigm on its head for effect.

Artists defied the established order with self-portraits. Until that time, there had been few examples of works in which artists painted themselves. As such, painting oneself was thought to be strange. In fact, "nearly without exception those painters who produced self-portraits were considered eccentric." ${ }^{n 3}$ Some artists during this time were referred to as 奇人 kijin, meaning "Odd person" or "Eccentric." 54 As someone living on the margins of mainstream society, these artists, both male and female, were exempt from the expectations normally placed upon them. While these labels may seem derogatory, they in fact freed the Edo period artist of some of the restrictions placed upon them by society.

Likely, many women artists during Edo bore the label of kijin because they were women. Weidner points out that women were commissioned for art during Edo primarily

\footnotetext{
${ }^{53}$ W. Puck Brecher, The Aesthetics of Strangeness Eccentricity and Madness in Early Modern Japan (Honolulu: University of Hawai'i Press, 2013), 189.

${ }^{54}$ Brecher, The Aesthetics of Strangeness Eccentricity and Madness in Early Modern Japan, 192.
} 
because they were "eccentric" and a novelty ${ }^{55}$ Female artists would have been sought out to paint commissions, especially by wealthy women, due to this perception of uniqueness. While not exclusively applied to female artists, terms like kijin show Edo period people's awareness of strangeness. Kijin artists succeeded in that they "expanded the view of what was acceptable and obtained cultural capital as a result. Some were criminalized, but this only allowed them more freedom to create weird art." ${ }^{56}$ In this way, kijin were not limited by the official role of art, nor to patrons that would demand more traditional themes and motifs.

Strangeness is a quality that is often discussed in European/American narratives of art. The term avant-garde was coined to describe art that pushed the envelope or had never been seen before. These artworks are often shocking and/or incomprehensible to most viewers, giving them a "high brow" mystique. Overall, to produce avant-garde art is highly valued in the West and is often a necessary quality to be considered a master of an artform. It is argued that one must be educated and cultured to fully appreciate such works. ${ }^{57}$ In Japan, though, innovation was not valued for its ability to challenge the status quo, but for its expressive qualities. Further, one did not have to eschew tradition to be considered a master. In fact, such an exercise would likely have been frowned upon.

This attitude toward strangeness is supported by the fact that several publications on Japanese aesthetics skip over the Edo period, as if the period produced no art worth

\footnotetext{
${ }^{55}$ Weidner, Flowering in the Shadows : Women in the History of Chinese and Japanese Painting, 235.

${ }^{56}$ Brecher, The Aesthetics of Strangeness Eccentricity and Madness in Early Modern Japan, 172.

${ }^{57}$ Clement Greenberg, Avantgarde Und Kitsch (na, 1939), http://sculpture.artapsu.com/wpcontent/uploads/2013/01/Greenberg-AvGdKtch.pdf.
} 
noting. ${ }^{58}$ The reasoning behind this may be the application of criterion in which "strangeness was evaluated on political power and innovation" rather than simply being examined and appreciated for its own merits. ${ }^{59}$ Often it is tempting to equate kijin with eccentric artists of Europe and the USA, those maverick masters who broke the mold and produced something avant-garde. To do so, though, does not account for the intent of Edo period artists, who often did not pursue strangeness itself but instead a "juxtaposition or negative of opposites" or "originality rather than idiosyncrasy for its own sake"60 These considerations illuminate misconceptions of the artist as revolutionary, while Edo kijin were not attempting to make a political statement at all. Instead, they were playfully exploring the boundaries of their art and what would happen when two opposites were placed together. Nevertheless, Japanese do not see this playfulness and discarding of tradition as a positive in all cases.

\section{Kiyohara Yukinobu (1643-1682)}

Kiyohara Yukinobu was the daughter of Kusumi Morikage, Kano Yan'yu’s pupil. ${ }^{61}$ As a disciple of the Kano school, the most powerful painting school in Edo period, Yukinobu came from a pedigree of official artists that contributed to her success. Further, she grew up in an important cultural center, Kyoto. With the success came limitations, though. Yukinobu was expected to follow the style of her mentors rather than her own personal expression, as was the case with many women artists and Kano pupils

\footnotetext{
${ }^{58}$ Brecher, The Aesthetics of Strangeness Eccentricity and Madness in Early Modern Japan, 174.

${ }^{59}$ Brecher, The Aesthetics of Strangeness, 206.

${ }^{60}$ Brecher, The Aesthetics of Strangeness, 183.

${ }^{61}$ Weidner, Flowering in the Shadows : Women in the History of Chinese and Japanese Painting, 230.
} 
in general. Within this framework, though, Yukinobu was able to produce artworks of her favored subject matter: female heroines. Among her work "there are numerous portrayals of female legendary and historical personages such as Murasaki Shikibu. Although these figures were occasionally painted by male Kano artists, the percentage in Yukinobu's case is higher, leading one to suspect that she herself favored these subjects, or that her patrons did." ${ }^{92}$

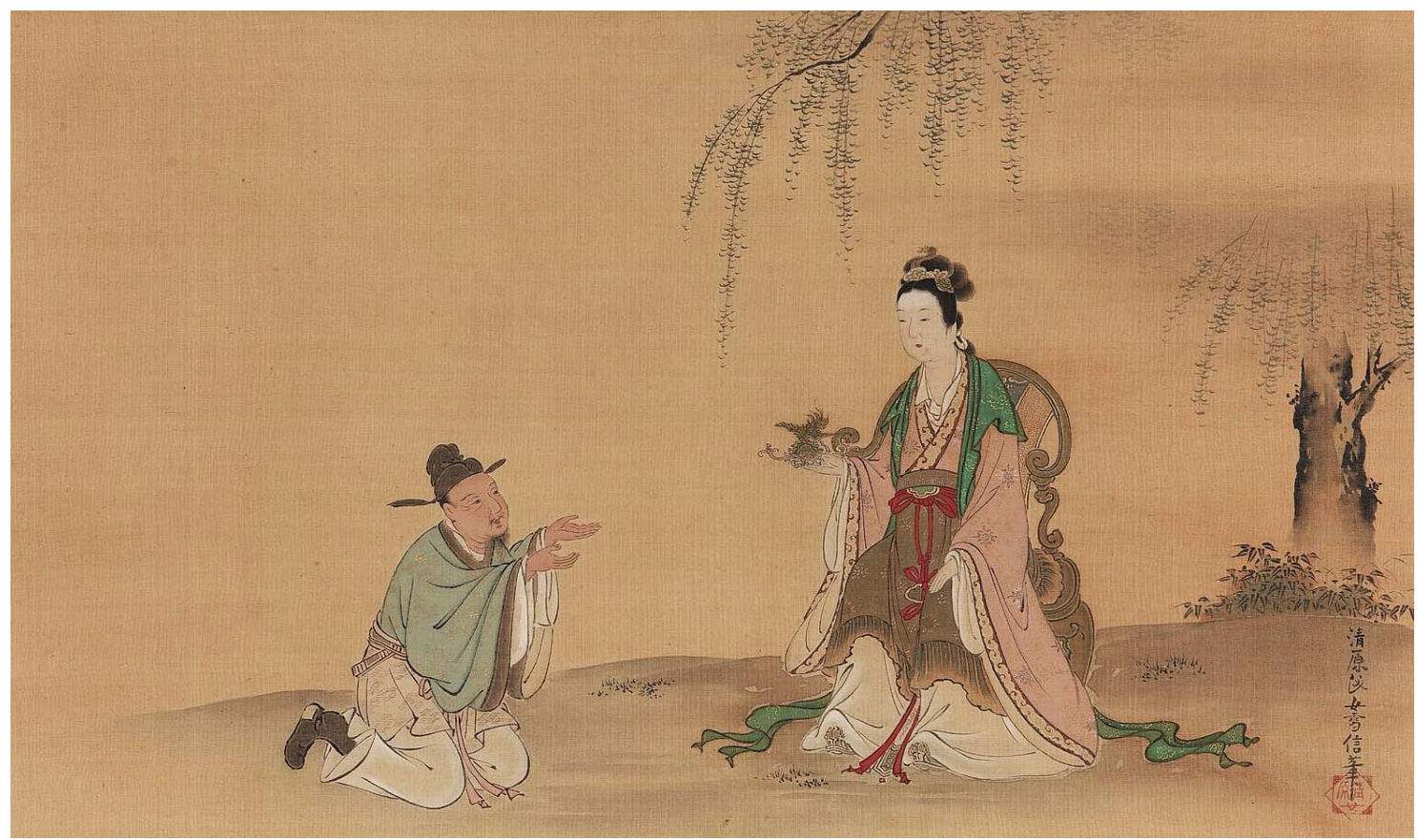

Figure IV-1 Kiyohara Yukinobu, Yang Guifei Giving Her Hair Ornaments to a Messenger. Late 17th century, Museum of Fine Arts, Boston.

In Figure IV-1, titled "Yang Guifei Giving her Hair Ornaments to a Messenger" Guifei sits gracefully atop an ornate wooden chair, in the shade of a flowering tree. Her placement is directly in the center of the composition, and she is the tallest, a place of honor in this case. A messenger kneels before her, ready to receive a phoenix hairpin that

${ }^{62}$ Weidner, Flowering in the Shadows, 230-33. 
Yang Guifei is holding in her hand. In Chinese mythology, the phoenix represents the feminine power of yin and would have adorned clothing and furniture used by the empress. If given by the emperor, such a trinket would symbolize his attitude toward Guifei. The piece has the typical Kano golden background, delicate, precise linework and vibrant colors. The pink, vibrant green and red of her robes may use Japanese seasonality to indicate spring, which is also reinforced by the choice of a blooming tree, indicating the cultural background of the artist. Yukinobu signed and stamped the painting in the lower right corner.

There is little record of who owned "Yang Guifei Giving her Hair Ornaments to a Messenger" during the Edo period. However, we know the provenance from Meiji to today. The work was first purchased by Ernest Francisco Fenollosa (1853-1908) prior to 1886. Ernest Fenellosa was a prominent art critic of Spanish origin who, with the help of Okakura Tenshin, was instrumental in constructing a conception of Japanese art history, forming schools and museums that would shape Japanese perception of art. The work was then purchased by Charles Goddart Weld in 1886, who later bequeathed the work to the Boston Museum of Art in 1911, where it remains. ${ }^{63}$ That Fenollosa acquired this work himself tells us about his preferences as an art critic: he chose a work that fits into the traditional Kano school style, with gold leaf background, delicate lines and vibrant colors.

63 "Yang Guifei Giving Her Hair Ornaments to a Messenger," Museum of Fine Arts, Boston, January 31, 2017, http://www.mfa.org/collections/object/yang-guifei-giving-her-hair-ornaments-to-a-messenger-24919. (One time fair use). 


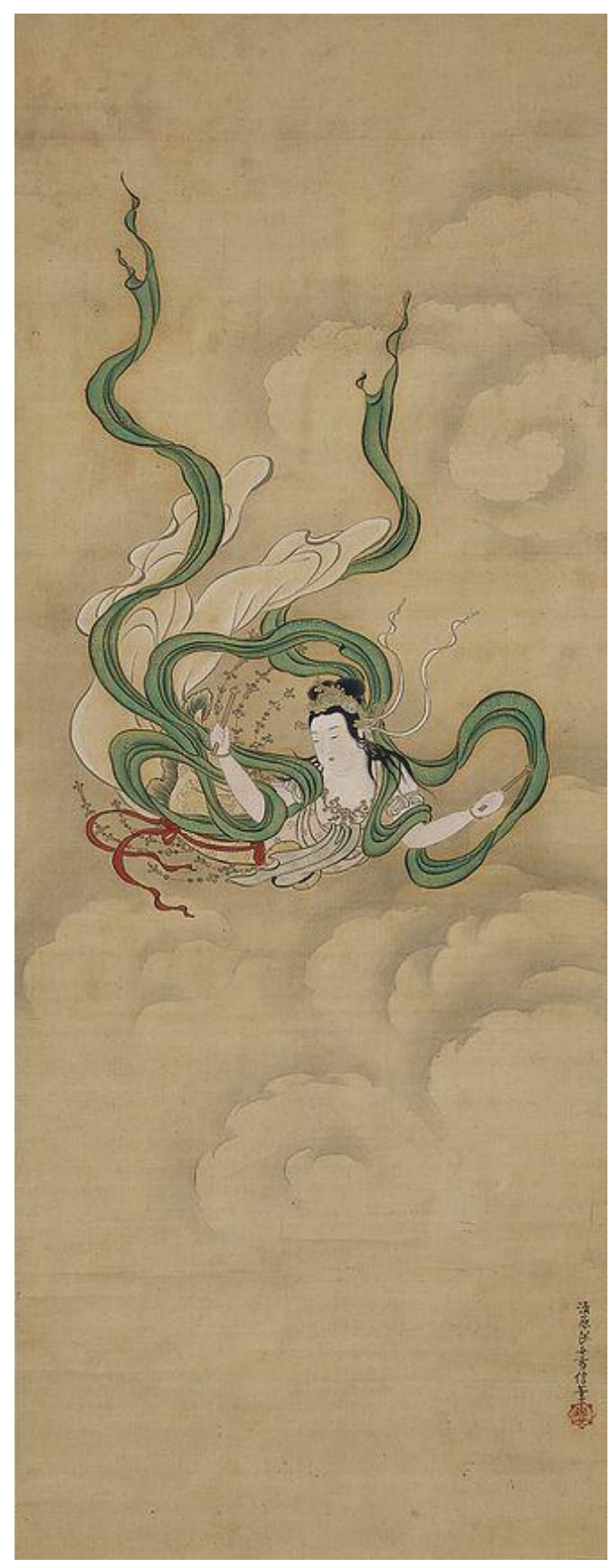

Figure IV-2 Kiyohara Yukinobu, Asparas (Flying Celestial). Late $17^{\text {th }}$ century, Minneapolis Institute of Art. $^{64}$

64 "Flying Celestial, Kiyohara Yukinobu^ ${ }^{\wedge}$ Minneapolis Institute of Art," accessed February 28, 2018, http://collections.artsmia.org/art/122129/flying-celestial-kiyohara-yukinobu. (One time fair use). 
Another famous example of Yukinobu's work, Figure IV-2 titled “Apsaras 飛天 (Flying Celestial)," shows a female spirit floating among clouds. Though these celestials were said to surround a buddha and were often seen in groups, ${ }^{65}$ the artist has chosen to focus in on an individual. The figure is situated near the vertical center of the work, though the trailing robes and scarves move upward and fill the top section of the work, creating an asymmetrical amount of empty space near the bottom. This lifts the figure and gives it a sense of weightlessness. The spiraling clouds below the figure add to this effect. The delicate line style, gold background and vibrant reds and greens are consistent with Yukinobu's other works and with the style of Kano in general. As with the first work, Yukinobu signed her work "Painted by the Woman of the Kiyohara Clan, Yukinobu." This is interesting because Yukinobu does not try to disguise her gender, as was the case with many authors and artists who adopted pen names. Instead, Yukinobu spells it out plainly.

Again, it is difficult to establish the provenance of this item in Japan. However, we do know that the work was acquired by Mary Griggs Burke (1916 - 2012), a prominent collector of Asian artifacts, and later donated to the Minneapolis Institute of Art by the Mary and Jackson Burke Foundation in 2015. Currently, the Mary Griggs Burke collection holds more than one thousand artworks from Japan, China and Korea. ${ }^{66}$ "Flying Celestial" is one of over 86,000 works not on display at the MIA. Nevertheless,

\footnotetext{
65 "Flying Celestial", Kiyohara Yukinobu^^ Minneapolis Institute of Art.

${ }^{66}$ Doshin. Sato, Hiroshi Nara, and Getty Research Institute (CA), Modern Japanese Art and the Meiji State : The Politics of Beauty (Los Angeles: Getty Research Institute, 2011), 57.
} 
the fact that such a work is housed in a permanent collection of the museum speaks to its desirability.

Fukuda Chiyo-ni (1703-1775)

Despite the relative intellectual freedom of artists and writers of the time, NeoConfucian moral codes were very restrictive to women. Relegated to roles as passive wives and mothers, most women did not frequently leave the home. The repressive society of Tokugawa inspired some artists to break off from the norm. As art historian and curator Martha Weidner explains, some women artists in Edo chose to eschew tradition to dedicate their lives to their artform. To achieve this goal, some noblewoman artists became Buddhist nuns. Doing so allowed them the freedom to travel, associate with male colleagues and eliminated the need to marry. ${ }^{67}$ Fukuda Chiyo-ni was one such woman.

Like Yukinobu, Chiyo-ni was born to a family with connections to the art world. Rather than being official artists, though, her parents were scroll makers. Chiyo grew up in Matto, Japan in Ishikawa prefecture. This area was much more rural that Kyoto, though it did have a major road where travelers would stop on their way to Kyoto. Overall, roles were less strict for women in Matto than Kyoto. One description of her early life says she "was born with a writing brush in her hand and with the scent of ink and poetry in the air." ${ }^{68}$ Her father encouraged her interest and talent by sending Chiyo-ni to apprentice under a haiku master named Hansui (1684-1775). This allowed Chiyo-ni to

\footnotetext{
${ }^{67}$ Weidner, Flowering in the Shadows, 220-21.

${ }^{68}$ Donegan et al., Chiyo-Ni: Woman Haiku Master, 25-40.
} 
learn Chinese characters, and overall she was better educated than many women of the time. ${ }^{69}$ While Chiyo-ni was born nine years after Bashō died, there were many disciples of his living in or around Kaga-Matto. Some of these famous artists included Hokushi (d. 1718), Manshi Ikoma, and Shiko Kagami (1665-1731), who became one of Chiyo-ni’s main poetry teachers. Her poems were first published in 1722, when Chiyo-ni was just nineteen, by the poet Rosen (1661-1743) after a group of Bashō's disciples got together to write. $^{70}$

In 1748, in her thirties, Chiyo-ni was hit with a series of tragedies that took the lives of both her parents, her brother and his wife. During that time, Chiyo was compelled to continue the family business in an act of filial piety. As such, she was not truly able to pursue her art since she was busy tending the shop. Eventually, she adopted a husband and wife into her home to inherit the family business, allowing her more time and freedom for artistic pursuits. ${ }^{71}$ Settling family affairs allowed her increased freedom, and Chiyo became part of a community of artists that collaborated and socialized together. Though it is unknown whether Chiyo-ni ever married, at the age of 52 she added the suffix "-ni" to her name, meaning nun. ${ }^{72}$ From this time until her death, Chiyo-ni was the most active in creating art. ${ }^{73}$

\footnotetext{
${ }^{69}$ Donegan et al., 28.

${ }^{70}$ Donegan et al., 30.

${ }^{71}$ Donegan et al., 25-40.

${ }^{72}$ Donegan et al., 25-40.

${ }^{73}$ Ibid.
} 
Like many kijin, Chiyo-ni led an unconventional life. Chiyo-ni was part of the Bashō school, a famous haiku school led by Bashō (1644-1694), perhaps the single bestknown Edo period artist. The school was known for their collaborative method of constructing poetry (in which several poets would participate) and their haiga (poem and painting) style. In a debate among artists, the school's founder Bashō "emerged in opposition to the Dinrin school of haiku (which emphasized humor) and started his own Shofu school." ${ }^{\text {74 }}$ Thus, Bashō was a highly regarded and powerful figure in the art scene of Edo. This did not mean it was easy for Chiyo-ni, since haiku was thought to be more objective and thus more appropriate for men than women. Nevertheless, there was historical precedent for women artists, especially as poets/authors. As a nun, Chiyo-ni was afforded a certain amount of respect and status. This allowed her more freedom to travel, as religious people were expected to make pilgrimages and visit various holy sites around Japan. In her travels she was able to visit other artists and collaborate on works in the style of Bashō and make a name for herself throughout Japan.

In addition to increased autonomy, Chiyo-ni's new title allowed her to associate with members of her school and develop a collaborative, shared style or language. There are examples in which Chiyo wrote the haiku and another artist illustrated. Letters written between Chiyo and fellow artists also elucidate in-person interactions and experiences with her colleagues. In this way, Chiyo-ni could participate in a dialogue regarding the nature of their art and what they as artists valued, in other words, their nomos. Chiyo-ni

\footnotetext{
${ }^{74}$ Maruyama, Studies in Intellectual History of Tokugawa Japan., 115.maru
} 
traveled not only to entertain visitors from her art school, but also to visit temples. Not tied down to any city or patron, Chiyo visited Kyoto and Ise.

Chiyo-ni produced many artworks during her lifetime, with 1,700 haiku attributed to her as far as we know. Perhaps her most famous is a work called "Morning Glory Haiku." In the case of this work, the calligraphy was produced by Chiyo-ni while the illustration that accompanies it is by Toho Naito. 


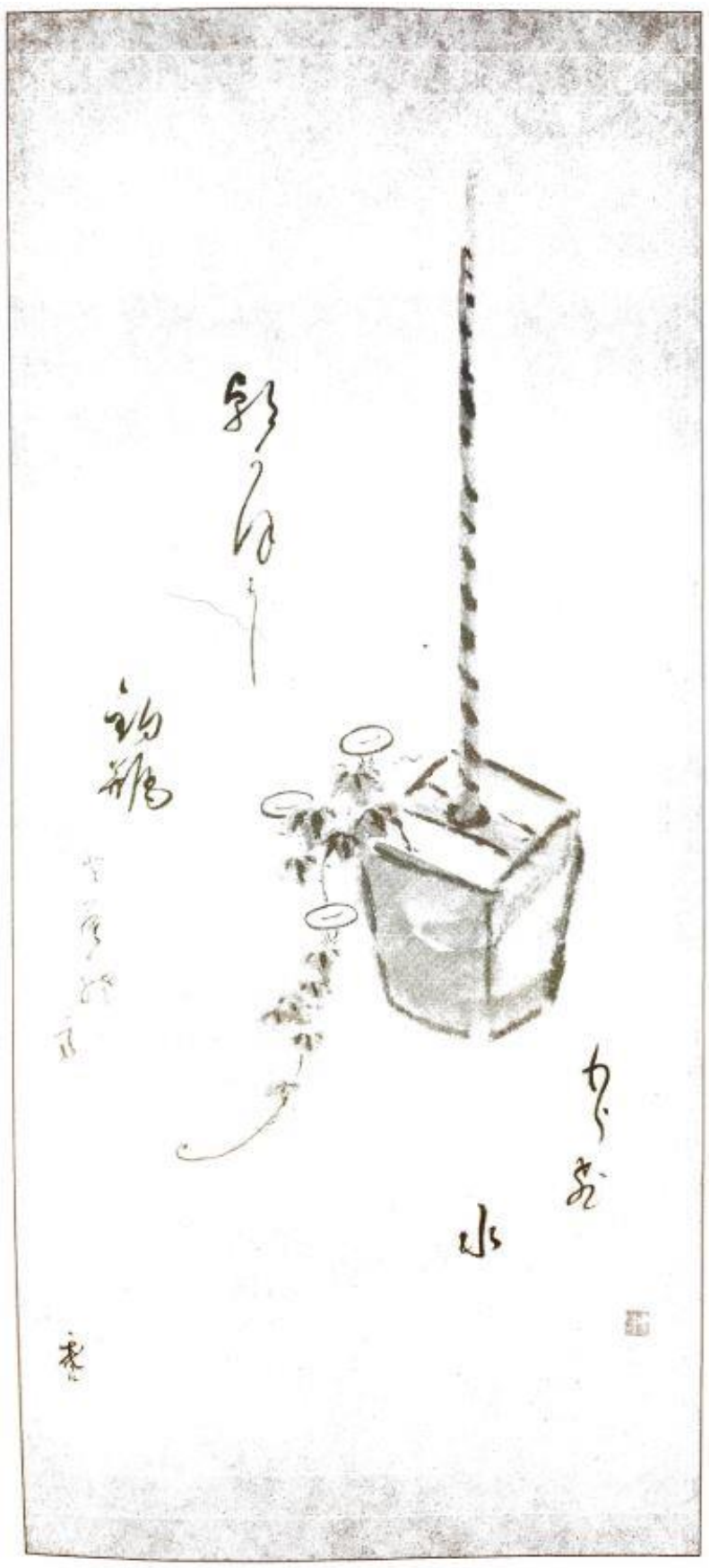

Figure IV-3 Fukuda Chiyo-ni and Toho Naito, Morning Glory Haiga. $18^{\text {th }}$ century, Matto City Museum. ${ }^{75}$

$\begin{array}{ll}\text { asagao ya } & \text { morning glory - } \\ \text { tsurube torarete } & \text { the well-bucket entangled } \\ \text { morai mizu } & \text { I ask for water }\end{array}$

${ }^{75}$ Donegan et al., Chiyo-Ni: Woman Haiku Master, 173. (One time fair use). 
Figure IV-3 is the visual representation of the "Morning Glory Haiku", perhaps Chiyo-ni's best known work. In this example, the painting directly illustrates the story told by the calligraphy. The right side of the work is dominated by the dark vertical line of the rope, which leads the eye down to the well-bucket itself. The tendrils of morning glory that sprout from the bucket seem to reach toward the delicate, grass style calligraphy, meaning its style appears loose and flowing rather than rigid. The alignment of the characters, as well, follows a roughly diagonal alignment but is otherwise freeform. The last line, "morai mizu," is done in faint ink, as if the request were whispered or weary. The arrangement of the calligraphy, bucket and rope create an asymmetrical, triangular composition. In the lower right, the artist has signed and stamped her name.

While not a particularly auspicious symbol, as was the case with bamboo and plum blossoms, the morning glory did have symbolic meaning. Flowers, in general, were representative of females, and were often "restricted to display in female spaces." ${ }^{, 76}$ In addition, the morning glory is associated with a story from Chinese folklore. As the story goes, two lovers neglected their household chores and duties, and were punished by being separated and only allowed to meet on one day of the year. ${ }^{77}$ While it is impossible to know whether Chiyo-ni had intended this meaning within her work, it seems to tie in with the longing for water (as the longing for a lover) and viewers would likely have been familiar with the tale. By incorporating familiar imagery in a unique way, Chiyo-ni plays with assumptions around categories and gives her own voice to the work.

\footnotetext{
${ }^{76}$ Screech, Obtaining Images : Art, Production and Display in Edo Japan, 43.

77 "Morning Glory Symbolism \& the Meaning of Morning Glories in the Language of Flowers," accessed April 9, 2017, http://livingartsoriginals.com/flower-morningglory.htm.
} 
Chiyo-ni did not focus exclusively on auspicious images, but the charm that she brings to representations of everyday objects has been noted by viewers of her work. This charm has resulted in continued popularity of her haiku and haiga, ${ }^{78}$ but the tendency toward whimsical images of everyday objects also catered to patrons of the time. Emphasis on portraying the real world in an accurate manner was a concern ${ }^{79}$ because it portrayed life, unvarnished and true. Chiyo's poems, which are often categorized based on the seasons, are very in tune with nature and laden with references to natural imagery. The political may have been partially avoided due to this personal, expressive nature, Chiyo-ni produced work without the intention of it ever being sold or coveted.

While most of Chiyo-ni's works were created without a patron in mind, there is one notable exception. In 1763, Chiyo "was once commissioned by the Maeda daimyo of Kaga to inscribe verses on a group of scrolls and fans which were then given by the Tokugawa shogunate to Korean envoys." ${ }^{80}$ While Chiyo-ni was not used to taking on the role of the oku-eshi, she produced 21 haiku and illustrations to accompany each of them. ${ }^{81}$ That Chiyo-ni would be commissioned to produce a work of that scale and importance speaks to her popularity during her lifetime. Chiyo-ni continued to produce works well into her 70s. As she and her artwork matured, her works mirrored more Zen-

\footnotetext{
${ }^{78}$ Pat Fister et al., Japanese Women Artists, 1600-1900, 1st ed. (Lawrence: Spencer Museum of Art, University of Kansas, 1988), 60-61.

${ }^{79}$ Screech, Obtaining Images : Art, Production and Display in Edo Japan, 25.

${ }^{80}$ Weidner, Flowering in the Shadows : Women in the History of Chinese and Japanese Painting, 234.

81 “About Chiyo-Jo Haiku Museum | Chiyo-Jo Haiku Museum,” accessed April 8, 2017, http://haikukan.city.hakusan.ishikawa.jp/english/about/index.html.
} 
like expressions. At age 71, she produced a self portrait that accompanies a poem written nearly twenty years earlier about becoming a nun:

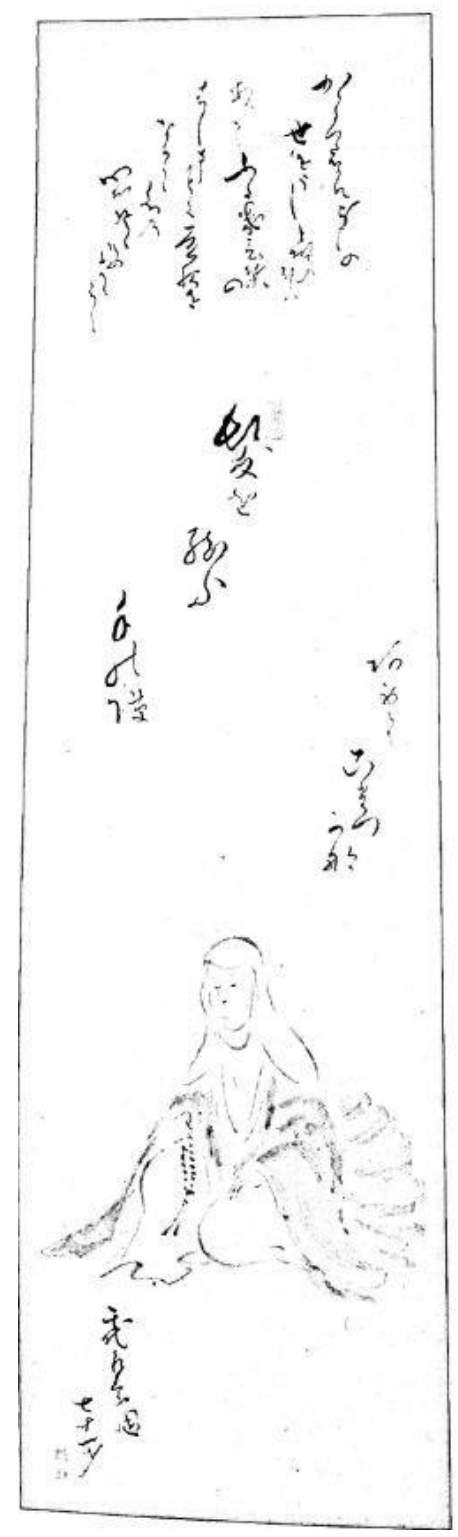

Figure IV-4 Fukuda Chiyo-ni, Self portrait. 1773, Nobutaka Aoki Collection, Matto City. ${ }^{82}$

Kami oh yu te no hima akete

Kotatsu kana putting my hair

no more-

my hands in the kotatsu

${ }^{82}$ Donegan et al., Chiyo-Ni: Woman Haiku Master, 209. (One time fair use). 
Figure IV-4 shows Chiyo-ni seated in a loose seiza (kneeling) position at the base of the composition. Her robes are shaded in with broad, watered down brushstrokes which contrast the delicate lines of Chiyo-ni's face and hood. The top of the composition contains a short passage and a haiku (in larger characters) which Chiyo-ni had written over 20 years before. The passage reads "I'm not shaving my head because I'm rejecting the world, but rather because I feel helpless and lonely thinking about the world of impermanence which is like a stream of water flowing night and day." 83 The calligraphy is very loose and, like the Morning Glory Haiku, adheres to a roughly diagonal composition while appearing freeform. The lowered head, sunken posture and droopy robes communicate a feeling of loneliness expressed in the passage. To shave her head was likely a drastic step for Chiyo-ni, and she may have felt it necessary to explain her reasoning. In the winter of her life, Chiyo-ni seeks the warmth of the kotatsu, a table covered in a blanket with a heater below it that was often used in wintertime to keep warm. The soft calligraphy, generous whitespace and delicate lines in the portrait lend the work a softness and stillness. The work is currently owned by the Nobutaka Aoki collection in Matto City. At the Dawn of Meiji

In late Tokugawa, Japanese people were introduced to Western thought and technology, which resulted in a myriad of reactions. Despite their limited interaction, Japan began to develop attitudes toward the "barbarians" from the West, not all of them favorable. In late Edo (1847), Nakamura Seisho wrote in Chimeki:

\footnotetext{
${ }^{83}$ Donegan et al., Chiyo-Ni, 208.
} 
The various countries of the West concentrate on machines and develop remarkable arts. They develop queer utensils and diverse skills to an inconceivable level. Because of this the Chinese people seem to conclude that foreigners are especially shrewd and intelligent. But this is foolish. To employ all one's intellectual faculties and deliberations for the manufacture of useless utensils and to invent trivial crafts, thus losing sight of one's spirit and fixed purpose, are matters motivated by caprice. They should be intensely despised." 84 Nakamura, then, seems to separate the intelligence of producing technology from spiritual intelligence and spirit. In this case, he views the Japanese as culturally superior because of intangible qualities of a spiritual and ethical nature. Thus, he was against the idea that technological advancements made one more civilized. Nevertheless, drastic changes occurred as a result of internal and external pressures in the Meiji period.

While Edo was a drastic period of change in the art world and social order in general, these shifts became even more pronounced in the Meiji Period (1868-1912) in which Japan fully opened itself to the world for trade, and travel beginning with the arrival of Commodore Perry's black ships. As we will see in the next section, Meiji art institutions saw many changes, including a shift in the power structure of art institutions: "a shift from traditional art schools or lineages to art organizations, from painting and calligraphy parties (shogakai) to art exhibitions, and from the workshop to the art schools. Conceptual changes included the recategorization of calligraphy,

\footnotetext{
${ }^{84}$ Maruyama, Studies in Intellectual History of Tokugawa Japan., 302.
} 
painting, and other antiques as artistic craft (bijutsu kogei), and painting technicians (gako) as painters (gaka) ${ }^{\prime 85}$

These changes would shape the perception of artworks and artists like Yukinobu and Chiyo-ni. As we will see, these changes often limited exposure of women artists.

${ }^{85}$ Sato, Nara, and Getty Research Institute (CA), Modern Japanese Art and the Meiji State : The Politics of Beauty, 44. 


\section{MEIJI TRANSFORMATION OF ART}

Introduction

When Japan opened ports beyond Nagasaki to the rest of the world at the end of the nineteenth century, little was known of the arts of Japan. The common narrative goes that due to their period of isolation, the Japanese were able to refine artforms such as tea ceremony, Noh, and calligraphy to the point of mastery. In Japan, these "refined" arts were not necessarily valued more highly than, say, a rough-hewn tea bowl. However, Japanese responded to the influence of the United States and Europe with both skepticism and admiration, with many attempting to emulate the Western approach to art. While Japan historically had elements of patriarchy and lack of recognition for women, these differences were broadened and perpetuated by the introduction of European and American models of art. In this way, women artists were excluded from the canon of art history and galleries. This had a transformative effect on art institutions in Japan.

In his book Becoming Art: Exploring Cross-Cultural Categories, author Howard Morphy points out that "The Eurocentrism of much art history of the past has created the impression that there are two kinds of art - art that is part of art history and art that is not." 86 While Morphy was discussing the construction of art history in aboriginal art of Australia, a similar process took place in Japan, resulting in similar outcomes. For example, scholars of aboriginal art debated whether it should be considered fine art or

${ }^{86}$ Howard Morphy, Becoming Art: Exploring Cross-Cultural Categories (Oxford ; New York: Berg, 2007), 1, http://www.loc.gov/catdir/enhancements/fy0743/2007033738-b.html. 
craft, and the individual artists' creativity and originality were applied to distinguish works. ${ }^{87}$

The distinction between art (sculpture and painting) and handicraft (objects for everyday use) was discussed in Immanuel Kant's The Critique of Judgment: The Aesthetic Representation of the Finality of Nature. In this work, Kant articulated a definition that boiled down to art being an expressive endeavor that did not produce items of practical use ${ }^{88}$ Kant's philosophies are seen in the art field today, and the influence is evident in the two categories of art created in Meiji era Japan. Two types of artforms developed: those made for export, which included ceramics, tea utensils and other handicrafts; and works for display in expositions, which favored paintings and sculptures. The selection of painting and sculpture for display followed the hierarchy of art established by European participants, and this hierarchy was later incorporated into official policies of Japan's Ministry of Education. ${ }^{89}$

Creating items for export required Japan to adjust to the pressures of an external market, and the need to consider "new contexts of use and display." 90 Art prior to Meiji would have been produced primarily for display in one of two contexts: the tea room or the bunten gathering. Thus, the venue of Japanese art changed from tea house to Western-

\footnotetext{
${ }^{87}$ Morphy, 141.

${ }^{88}$ Immanuel Kant, "The Critique of Judgment: The Aesthetic Representation of the Finality of Nature," in The Nature of Art : An Anthology, ed. Thomas E. Wartenberg, 1st ed. (Boston, MA: Wadsworth Cengage Learning, 2012), 57.

${ }^{89}$ Sato, Nara, and Getty Research Institute (CA), Modern Japanese Art and the Meiji State: The Politics of Beauty, 68.

${ }^{90}$ Morphy, Becoming Art: Exploring Cross-Cultural Categories, 119.
} 
style art gallery, with Western-style framing, rather than scroll mounting, becoming more commonplace. Some Japanese sarcastically used the term tenrankai geijutsu or exhibitionary art, in disdain for this trend. ${ }^{91}$ The introduction of Euro-American art ideals resulted in a faction divide between two groups, the "old" style led by Sano Tsunetami and Yamataka Nobutsura and the "new" school spearheaded by Okakura Tenshin. ${ }^{92}$

Not only did the influx of Westerners cause Japanese to debate the future of art, but also resulted in the need adapt to increased demand for Japanese goods. The French term "Japonisme" was coined in France to describe the frenzy for Japanese art during this time. While the exhibition space demanded large-scale paintings and impactful sculptures, French art connoisseurs favored craft items. Whereas the "official" hierarchy of Japan placed oil painting and sculpture at the top, everyday Japanese still preferred ink paintings. In some cases, “artworks were accumulated with collectors' specific preferences in mind and, in most cases, before the works were highly appraised in Japan."93

French people had a taste for tea bowls, calligraphy, and other artforms that were falling out of official favor during this time. Famous tea bowls and chaire (tea caddy) like Rikyu shiribukura, came with a story and history of tea that went back many years. ${ }^{94}$ This liked satisfied a French desire for something exotic and unusual in everyday life. Some

\footnotetext{
${ }^{91}$ Masaaki Morishita, "The Empty Museum : Western Cultures and the Artistic Field in Modern Japan," 2016, 41-48, https://nls.ldls.org.uk/welcome.html?ark:/81055/vdc_100029782442.0x000001.

${ }^{92}$ Sato, Nara, and Getty Research Institute (CA), Modern Japanese Art and the Meiji State : The Politics of Beauty, 50.

${ }^{93}$ Sato, Nara, and Getty Research Institute (CA), 130.

${ }^{94}$ Shimizu, Japan: The Shaping of Daimyo Culture 1185-1868, 350-51.
} 
Japanese painters of this time had begun to work in a more Western style, which did not interest the French. In response to the demand, the Japanese government instituted various policies to stem the outflow of artworks and preserve national treasures. ${ }^{95}$

The emphasis on preservation of works impacted art history as a discipline in Japan and caused "an institutional separation between painting and sculpture on one hand and artisanal work on the other." 96 Works chosen to be preserved and those that were written about in art historical accounts were closely linked and influenced each other. These works also tended to end up in galleries in the West, ${ }^{97}$ as was the case with Yukinobu's work. There were several major players who shaped the choices of works, including Machida Hisanari (1838-1897), who was appointed by the Ministry of Education; Ernest Fenellosa, a well-known Orientalist who gave lectures on Japanese art history and popularized term nihonga, meaning Japanese painting; and Okakura Tenshin, who wrote The Ideals of the East and The Book of Tea. Tenshin, with Fenellosa, founded the Tokyo University of the Arts and became a kind of cultural ambassador and expert in all things Japanese. The actions of these men individually shaped the perception of Japanese art during Meiji and later years.

Several social factors influenced the selection of artworks to preserve and display, including strangeness, which led to issues of categorization and excluded calligraphy from the official narrative; transculturation, which applied European/American ideals of

\footnotetext{
${ }^{95}$ Sato, Nara, and Getty Research Institute (CA), Modern Japanese Art and the Meiji State: The Politics of Beauty, 106.

${ }^{96}$ Sato, Nara, and Getty Research Institute (CA), 57.

${ }^{97}$ Sato, Nara, and Getty Research Institute (CA), 163-64.
} 
"good" or "fine" art to Japanese art history; and Hegemony, which re-enforced the established order and distribution of power and wealth through the artworks chosen. Though these factors existed to some degree prior to Meiji, they were amplified during this period due to extensive interactions with the West and resulted in a myriad of changes to how the Japanese viewed their art, as well as how it was sold and marketed in a global context. These changes impacted many lesser known artists but were especially unforgiving to female artists.

\section{Strangeness}

In this context, strangeness refers to the weird, eccentric, sometimes ugly art of Edo period Japan. Further, it refers to the contextual strangeness and uniqueness of Japan that made it interesting to European and American viewers. $18^{\text {th }}$ century philosopher and historian David Hume (1711-1776) wrote influential essays on aesthetics and taste. He argued that "beauty and deformity, more than sweet and bitter, are not qualities in objects, but belong entirely to the sentiment." 98 Thus, artwork was an expression of preferences from the foreign culture of Japan. Looking for something new and exotic, many consumed cultural objects, performances and stories that teemed with Otherness. As with many other forms of media, reports of the strangeness of Japanese culture were "greatly exaggerated." Nevertheless, it was a very prevalent narrative that is still used today to generate interest in Japanese art.

The Vienna International Exposition was the first official showing of Japanese goods by the Meiji government. They "built a Shinto shrine and a Japanese garden

\footnotetext{
${ }^{98}$ David Hume, "Of the Standard of Taste," in The Nature of Art: An Anthology, ed. Thomas E. Wartenberg, 1st ed. (Boston, MA: Wadsworth Cengage Learning, 2012), 40.
} 
featuring a white wooden gate [...] music and dance hall, and an arched bridge." 99 By that time, Europeans had nearly 20 years of experience in this environment. As newcomers, art critics in Japan were disappointed by the lack of attention their artworks received at global exhibitions. ${ }^{100}$ This prompted various adaptations of the types of works chosen. As mentioned previously, international audiences expected "Japaneseness", something that was peculiar to Japan. They expected works such as expressive calligraphy, or those that promoted a feeling of Zen and spirituality. The led to a divide in Japan between those who wished to promote old art and those who wanted to adopt European styles. This conflict is present in the official vs. private preferences outlined above and in institutional debates among art historians of the time.

In global art exhibits of the time, success was measured by how well the work was received by an international audience. In some cases, Japanese paintings were not accepted as such, but were considered drawings by Europeans. This shows the difficulty of fitting "strange" nihonga (Japanese painting) into traditional, European categories. Rather than give up in the face of these challenges, the Japanese emphasized their difference as a selling point. By explaining the cultural context of the works, nihonga uniqueness could be appreciated and sold. ${ }^{101}$

One high-profile debate took place between Koyama Shotaro and Okakura Tenshin. Koyama had published an article in which he criticized the inclusion of

\footnotetext{
99 "Vienna International Exposition and Japonism | Part 1: Expositions Held in and before 1900 | Expositions, Where the Modern Technology of the Times Was Exhibited," accessed September 3, 2018, http://www.ndl.go.jp/exposition/e/s1/1873-2.html.

100 Tomoko Mamine, “Displaying Globality,” Third Text 27, no. 4 (2013): 502-9.

${ }^{101}$ Mamine, "Displaying Globality," 505.
} 
calligraphy in modern exhibits since they outnumbered paintings. He argued that calligraphy had neither the colors of painting nor the moldable quality of sculpture, and thus was inferior. In response, Tenshin argued for a more inclusive definition of art that would include "music, poetry, sculpture, paintings, architecture, and ceramics." 102 However, he never explicitly argued for the inclusion for shoga within bijutsu. These debates, though, show that scholars and art critics were still forming the conception of this term and had not yet agreed on its form. This reality points to difficulty in applying the new framework in a Japanese context.

The strangeness of Japanese art in an exposition also resulted in a rethinking of categories of art. It was not until the early 1870s that the term bijustu, used to indicate art or fine art, was used in Japan. This term was invented when the European concept of art and writings on the topic were translated into Japanese. Bijustu is understood to refer to visual and figurative arts, while excluding literature, music and theatre. ${ }^{103}$ The use of the term carries with it the weight of European categories, which do not apply to Japan neatly. One artform of particular interest is calligraphy, shoga in Japanese.

Calligraphy in Japan did not fit neatly into either calligraphy or painting. In the case of Chiyo-ni, her haiga works had elements of both calligraphy and illustration. At first, Japanese saw shoga as a unique category of painting which could be further subdivided by medium. This was first done at Dai Nihon naikoku kangyo hakurankai kaijo shiki no zu 大日本内国勧業博覧会開場式之図 (Opening Ceremony of the Imperial

\footnotetext{
${ }^{102}$ Mamine, "Displaying Globality," 509.

${ }^{103}$ Morishita, "The Empty Museum: Western Cultures and the Artistic Field in Modern Japan," 5.
} 
Japanese Domestic Industrial Exposition) ${ }^{104}$ a show hosted in Japan by the Japanese government to promote Japanese art, specifically art with industrial or domestic applications. The issue of calligraphy was also addressed by the Okakura-Koyama debates discussed above.

In later expositions, likely in response to European demand and norms, calligraphy was moved to a miscellaneous category where it had previously been considered part of painting/fine art. ${ }^{105}$ This change signified an official attitude toward calligraphy that placed it below painting in the hierarchy. According to Morishita, calligraphy was removed from art due to institutionalization. Shoga, due to cultural association with China, came to be viewed less and not seen as fine art. It was also practiced not only by those of high rank but commoners. It fell out of favor officially but continued to be practiced in private. ${ }^{106}$ Thus, calligraphy was still created, even cherished, in Japan, but it was not suitable for display in a global context. For the first time in Japan, works that used to exist side by side were pushed into separate categories and spaces. ${ }^{107}$ One could say the "strangeness" if calligraphy forced it out of favor in a country concerned with being relevant in a global context.

\footnotetext{
${ }^{104}$ Morishita, "The Empty Museum," 39.

${ }^{105}$ Sato, Nara, and Getty Research Institute (CA), Modern Japanese Art and the Meiji State : The Politics of Beauty, 189.

${ }^{106}$ Morishita, “The Empty Museum: Western Cultures and the Artistic Field in Modern Japan,” 90-91.

${ }^{107}$ Rosina Buckland, Painting Nature for the Nation: Taki Katei and the Challenges to Sinophile Culture in Meiji Japan (Brill, 2012), 7.
} 


\section{Transculturation}

Japan's concern for keeping up with the West is encapsulated in the motto bunmei kaika (being civilized). The phrase first appeared in print in 1868, and often implied an uncritical acceptance of Western civilization and ideals. ${ }^{108}$ It was not without its critics, however; in 1879, Yoshioka Noriaki wrote: "There are two ways of being civilized. One is to be civilized in mentality, and the other is to be civilized in material objects. To be civilized mentally is the foundation and material civilization is based on it."109 Japan distinguished being civilized in a moral/mental way from having technology and material objects. Despite conflicting ideas about Western influence in Japan, there are numerous examples in which bunmei kaika manifested itself in art, religion, customs, and practices. Some, like Ozaki Hiromichi, took it so far as to say the introduction of Christianity would result in a "great revolution in Japan [...] not only in politics, but in society in general." 110

The result of bunmei kaika was somewhere between assimilation and rejection. Fernando Ortiz argues that "the result of every union of cultures is similar to that of the reproductive process between individuals: the offspring always has something of both parents but is always different from each of them." He uses the term "transculturation" to

\footnotetext{
108 Michio Kitahara, "The Rise of the Four Mottoes in Japan: Before and After the Meiji Restoration," Journal of Asian History 20, no. 1 (1986): 54-64.

${ }^{109}$ Yoshioka Noriaki, "Kaika Honron", in Meiji Bunka Zenshū, Vol. 20, ed. Yoshino Sakuzo, (Tokyo, 1929; originally 1879), p. 295

${ }^{110}$ Kitahara, "The Rise of the Four Mottoes in Japan: Before and After the Meiji Restoration."
} 
describe this union of cultures and applies it to the experience of native Cubans. ${ }^{111}$ While the post-colonial context does not apply directly to Japan, one could say that the historical circumstances of a country does not necessarily exclude it from being viewed through the lens of transculturation. In Japan, there was a great deal of cultural colonization, especially in art, which can be examined.

Art and culture in Japan, until Meiji, had been heavily influenced by China. However, the influence shifted dramatically from China to "the West" during the EdoMeiji transition. This led to the introduction of Western art concepts while maintaining “Japan's traditional sensibility toward the beauty of crafts that people enjoyed in their daily lives." 112 At the same time, works that existed outside of the commonplace were elevated due to the high-low dichotomies imported from Europe. This difference in preferences of "everyday" Japanese and the official narrative which emphasized fine art (high) categories over craft (low) still has implications for the treatment of art in Japan today. $^{113}$

One primary effect of an integration of West/East was that it placed curators and art historians in a position where they needed to mediate between groups that advocated for nationalism or globalism. ${ }^{114}$ Since Japan, up to this point, did not have a uniform concept of art history and instead relied on individual art schools to develop a pedigree of

\footnotetext{
${ }^{111}$ Fernando Ortiz, Cuban Counterpoint: Tobacco and Sugar (Durham and London: Duke University Press, 1995), http://www.personal.psu.edu/users/s/a/sam50/readings521/ORTIZ_Counter-Engl.pdf.

112 Sato, Nara, and Getty Research Institute (CA), Modern Japanese Art and the Meiji State : The Politics of Beauty, 57-59.

${ }^{113}$ Sato, Nara, and Getty Research Institute (CA), 134.

${ }^{114}$ Morishita, “The Empty Museum: Western Cultures and the Artistic Field in Modern Japan,” 96.
} 
art, the Japanese relied heavily on European aesthetics when selecting artists for inclusion in the canon of their art history. This resulted in a canon of art history that elevated some artworks and artists while others were not included.

Until Meiji, the Japanese did not have a uniform concept of art history, with various accounts (often conflicting) being brought forth by competing art schools. Marra describes art history as "A Western product" that was "alien to the East Asian Cultural sphere in the nineteenth century." Further, he argues that these ideas were not native to Japan and instead were constructed in response to and in imitation of the West. ${ }^{115}$ If one can buy in to art history as "grounded in the common-sense knowledge and experience of members of the societies in which they develop"116 then the importation of Western art history into Japan brought with it assumptions and experiences native to those cultures rather than Japan. As such, the discipline itself favored certain styles and expressions which reflected preferences and knowledge of the West.

One European aesthetic principle that was imported to Japan was avant-garde, in which artists were admired for their ability to push the envelope. Such views are incompatible with the more introspective, emotional work of Chiyo-ni. As such, many works that would have been previously treasured in Japan for their emotive, subtle aspects were largely ignored in favor of more extraverted pieces. Examples of more extraverted, strange and cutting edge artists might include Hokusai, Buson, etc. While

\footnotetext{
${ }^{115}$ Michele. Marra, Japanese Hermeneutics : Current Debates on Aesthetics and Interpretation (Honolulu (T.H.): University of Hawai'i Press, 2002), 115.

${ }^{116}$ Morphy, Becoming Art: Exploring Cross-Cultural Categories, 147.
} 
such works are certainly deserving of attention, they all share similar characteristics that adhere to Western ideals of the avant-garde.

Another aesthetic principle that influenced Japanese art historians was the artist as author. This principle places the value of the work on the intent of the artist and gives credit to their individual creativity rather than seeing the work within the context of institutions. However, much of Japanese art was produced within the confines of an artist school, with mentors instructing pupils in proper technique, subject matter, and style. In some cases, artworks were signed by the teacher even though they were produced by the pupil. In others, they were signed merely with the school name and not attributed to an individual. This idea runs counter to the European perception of the artistic Master who forges his own way and creates his artworks in a kind of creative vacuum. Japanese artists that might fall into this category of "Master" were exclusively male due to the inheritance system in which the father transmitted artistic secrets to the son, who would be expected to lead the school and take small risks while maintaining a style consistent with his ancestors. ${ }^{117}$ Beyond selection of works, aesthetic values shaped the production of new works for a new market. However, that is beyond the scope of this thesis.

In Hume's words, 'It is natural for us to seek a Standard of Taste; a rule, by which the various sentiments of men may be reconciled; at least, a decision, afforded, confirming one sentiment, and condemning another." 118 This standard of taste, applied to Japan, shaped not only artworks produced but the formation of institutions that dealt with

\footnotetext{
${ }^{117}$ Robert F. Arnove and Ryohei Matsuda, "Japanese 'Living National Treasures' in the Arts," Education and Society 27, no. 2 (2009): 45-54.

${ }^{118}$ Hume, "Of the Standard of Taste," 40.
} 
art. The next section will discuss these issues in more detail using hegemony and symbolic power, two interrelated theories, as a framework for understanding.

\section{Hegemony/Symbolic Power}

Pierre Bourdieu described symbolic power as "a form of knowledge, an internalized code or cognitive acquisition which equips the social agent with empathy towards, appreciation for or competence in deciphering cultural relations and cultural

artefacts." ${ }^{119}$ In this context, symbolic power means the subtle signifiers of wealth, status and power that are implied through possession, patronage and creation of artworks. Hegemony is the dominant (military, cultural, or both) force in a society. ${ }^{120}$ In this case, the hegemony in place is an ethnic Japanese, wealthy male, one. However, the United States and Europe also became an important cultural hegemony in Japan during Meiji. Art in Japan was not merely a means for personal expression but aided in constructing state narratives and enforcing dominance over marginalized people. In an art gallery, selection of works conformed to state narratives since those in power were often the patrons of art. This led to many woman artists being excluded from viewing, since most powerful figures of Japanese art had been male.

In later periods, the audience for displays of wealth and power was globalized. While some Japanese embraced Western artistic ideals during Meiji, others felt threatened by them. Japanese artists needed to sell the symbolic power of "Japaneseness"

\footnotetext{
${ }^{119}$ Pierre Bourdieu and Randal Johnson, The Field of Cultural Production : Essays on Art and Literature (Cambridge: Polity Press, 2016), 6.

${ }^{120}$ Walter L. Adamson and Antonio. Gramsci, Hegemony and Revolution (Berkeley: University of California Press, 1980).
} 
since it was what international audiences expected. This galvanized those who sought to promote Japanese superiority. Kristin Surak explores how the Japanese tea ceremony has been used to promote national interests and re-enforce power structures. She argues the social system of traditional artforms, iemoto or head of household, resulted in a consolidation of cultural power to the male masters (iemoto) of the art schools. This use of art as symbolic power has precedence in Edo period art and applies further to art objects used in tea ceremony such as paintings, ceramics, lacquerware and bamboo utensils.

As keepers of the traditional arts, which were often transmitted verbally from Master to disciple, iemoto wielded a great deal of power over cultural capital. Art was a symbol of status and wealth and became an expected part of education. In modern times, tea practitioners have formalized their institutions into "tea schools" with certifications and prescribed (written) methods. Rather than diminish the role of the iemoto in tea schools, formalization made these men even more important. Hume said "though the principles of taste be universal, and nearly, if not entirely, the same in all men; yet few are qualified to give judgment on any work of art, or establish their own sentiment as the standard of beauty." ${ }^{121}$ The view that some men were better qualified to judge artworks seems to have taken place in Japan as well. As the sole authority over tea utensils, certifications, and ceremony etiquette, the iemoto became an indispensable part of the traditional art scene in Japan, shaping which artworks were selected for preservation and display.

\footnotetext{
${ }^{121}$ Hume, "Of the Standard of Taste," 44.
} 
Elaborating on this idea, other scholars profiled seven artists from traditional schools, focusing especially on how traditions were transmitted. In the 1950s, The Agency of Cultural Affairs of the Ministry of Education and Science designated a title of "Living National Treasures" to be given to masters of various categories of Japanese art. ${ }^{122}$ To qualify for this title, one must usually be a blood member of a family. Additionally, yearly art competitions were held by art schools around Japan, and students who did not have the support of a iemoto would have little chance of being involved in an art competition, receiving prizes or recognition. Thus, modern women artists and other marginalized populations are rarely recognized even today.

In art galleries, the iemoto manifests itself in criticism against the inclusion of newcomers to the art scene. At the Tokyo Metropolitan Museum, many art critics desired to see more work by the masters of Japanese art. Often, this results in curators having to play a careful, conciliatory role to please both the new artists and those looking for traditional works. They found themselves trapped between political groups advocating for nationalism or globalism. This resulted in exhibits of works not organized thematically or thoughtfully but instead inclusively in order to represent all possible groups. Unfortunately, artists like Chiyo-ni and Yukinobu were less likely to be chosen than the iemoto of their art schools, Bashō and Kano respectively.

A measure of Japanese confidence in their own cultural and economic power is to look at the prevalence of art galleries from 1950-today. Looking at major trends, one can conclude that there was a boom in museums with "extensive collections of Japanese art"

${ }^{122}$ Arnove and Matsuda, "Japanese 'Living National Treasures' in the Arts." 
in the $1970 \mathrm{~s}-90 \mathrm{~s}$, directly correlating to the economic boom of that time. ${ }^{123}$ This supports the idea that Japanese art is a way for Japanese to assert their cultural dominance. At the height of their positive feelings about the Japanese economic model, they had the largest collections of Japanese art. To expand this trail of research, it would be interesting to look at whether museums owned works by Chiyo-ni and Yukinobu at that time. Today, by contrast, few museums in Japan house permanent collections of Japanese art and often bring in exhibits of foreign masters. This idea is echoed by economist Gordon Burt (1997), who thought the prevalence of Western works were indicative of "a change in the shares in the consumption of distinct cultural goods in Japanese society." In other words, some cultural goods were given more value and representation depending on the context. The work of an influential founder of an art group would have had more cultural "shares" since it was symbolic of status and the contributions of that individual.

Other than a survey of museum visitors and the construction of new facilities, there is very little quantitative analysis of the "symbolic power" theory in relation to Japan. This may be due partially to the nature of the topic, which seems to lend itself more to a comparative analysis of attitudes and institutions. However, more work could be done to get a more grounded understanding of Japanese attitudes toward art. One criticism of history and broad analysis of trends is that it is often based on the words of those in power. However, there are a multitude of experiences and viewpoints, especially

\footnotetext{
${ }^{123}$ Morishita, "The Empty Museum: Western Cultures and the Artistic Field in Modern Japan,” 100.
} 
in the field of art. Often, these leads to curators being placed in a mediator position between political groups advocating for different priorities. ${ }^{124}$

In the late Meiji period, there was a push to preserve artworks of cultural value. By 1907, Ministry of Education and newly formed art colleges (such as the Tokyo Art College) had formed a collection of "classics" of Japanese art. ${ }^{125}$ At the same time, the Ministry formed the Bunten 文展 (Exhibition) to showcase such works. The Bunten became the authority regarding "masterpieces of the past" However, these works were far from representative of the entire span of Japanese artistic production. Instead, most works chosen for preservation were "items in the imperial household and in temples and shrines around the nation." ${ }^{, 26}$ This resulted in a collection of works tied to the premodern and modern power structures. Further, this meant that more works of painting and sculpture were elevated and separated from "artisanal work." 127 Artworks chosen for preservation, too, were often the subject to art historical accounts. In this way, there was a correlation between works included in collections and those written about and tied in with the uniform narrative of Japanese art history. ${ }^{128}$ This idea is best summarized in the following quotation from an essay published in Japanese Hermeneutics: Current Debates on Aesthetics and Interpretation:

\footnotetext{
${ }^{124}$ Morishita, "The Empty Museum," 96.

${ }^{125}$ Morishita, "The Empty Museum," 34.

${ }^{126}$ Sato, Nara, and Getty Research Institute (CA), Modern Japanese Art and the Meiji State: The Politics of Beauty, 52.

${ }^{127}$ Sato, Nara, and Getty Research Institute (CA), 57.

${ }^{128}$ Sato, Nara, and Getty Research Institute (CA), 163-64.
} 
It was in this narrow margin between compatibility with Western standards and irreducibility to Western products and tradition that the selection was to be conducted, consciously or unconsciously. Moreover, the selection of "masterpieces" creates rejected objects as their inevitable counterpart, objects that fall out of the "fine arts" category. The interplay between the selected and the rejected reveals hidden mechanisms in the formation of masters and masterpieces in the field of Japanese art history. ${ }^{129}$

Thus, Japanese art history was filtered through a Western lens. Along with the creation of canon "masterpieces" was the inevitable creation of a substantial number of rejects that did not make the cut. As the quotations mention, though, such decisions were not always conscious or intentional. Nevertheless, many scholars have identified Japanese art history as a largely Western import and have explored the implications of such an adoption.

${ }^{129}$ Marra, Japanese Hermeneutics : Current Debates on Aesthetics and Interpretation, 63. 


\section{JAPANESE ART TODAY}

Modern Reception of Chiyo-ni and Yukinobu

In response to the popularity of Chiyo-ni's haiku in Japan, Hakusan City (formerly Chiyo's hometown of Matto) adopted the morning glory as its favorite flower ${ }^{130}$ A museum called the Chiyo-jo Haiku Museum was also established there, and visitors, even children and foreigners, are encouraged to write and turn in their own haiku poems. Outside the museum is a statue of Chiyo-ni along with an engraved plaque with information about her. Shokouji temple in Hakusan may house some of her personal effects, as well. These attempts to memorialize Chiyo-ni show the impact her poetry has had on Japanese people. It is difficult to quantify, but it seems many or familiar with, at least, her Morning Glory haiku.

Modern scholars are not in agreement about the role that Chiyo-ni should play in art history. Buddhist Scholar D.T. Suzuki (1870-1966) felt the haiku represented evidence of Chiyo-ni's enlightenment and a complete detachment from the self. He writes "At the time, the poetess was not conscious of herself or of the morning glory standing beside her. Her mind was filled with the flower, the whole world turned into the flower, she was the flower itself." ${ }^{131}$ Suzuki's understanding of Chiyo-ni centers around her enlightenment under a Zen master, who taught her the importance of letting go of ego in haiku. In Suzuki's words, “The greatest productions of art, whether painting, music, sculpture, or poetry, have invariably this quality - something approaching the work of

\footnotetext{
130 “About Chiyo-Jo Haiku Museum | Chiyo-Jo Haiku Museum.”

${ }^{131}$ Donegan et al., Chiyo-Ni: Woman Haiku Master, 88-90.
} 
God. The artist, at the moment when his creativeness is at its height, is transformed into an agent of the creator. This supreme moment in the life of the artists, when expressed in Zen terms, is the experience of satori." ${ }^{132}$

But Chiyo-ni was not without critics. R.H. Blyth (1898 -1964), a notable translator of haiku that Suzuki also quoted, argued that women could not write haiku and even if they did, they would be "only fifth class." A Japanese critic named Kyoshi Takahama (1874-1959) seemed to hold similar attitudes when he said women haiku artists were "too subjective and downgraded haiku." ${ }^{133}$ In discussing the morning glories haiku, he felt it did not show enlightenment or kindness, but conceit and ridiculousness. ${ }^{134}$ This view of women is inferior in haiku was likely informed by personal bias, but also seems to be rooted in the historical difference between waka, which women were known for in Heian, and the more abbreviated haiku, which was thought to be more objective and manly.

Contrasting Chiyo-ni and Yukinobu in Galleries Today

Overall, by looking at these two artists and the locations of their artworks, one could conclude that most of Chiyo-ni's calligraphy and haiga remain in Japan while many works of Yukinobu are housed in galleries in the United States and Europe. Table VI-1 shows the titles, locations, and credit lines of several works by both artists. While it is by no means an exhaustive collection of works, I did not find an example of a work of

\footnotetext{
${ }^{132}$ Daisetz T. Suzuki, Zen and Japanese Culture : With a New Introduction by Richard Jaff (Princeton, N.J.: Princeton University Press, 2010), 220-24.

${ }^{133}$ Donegan et al., Chiyo-Ni: Woman Haiku Master, 86.

${ }^{134}$ Donegan et al., Chiyo-Ni, 86.
} 
Chiyo-ni housed in the United States. Most (if not all) of her works are housed in Matto

City, either in the Matto City Museum or Chiyo-jo Haiku Museum. By contrast, there are many works of Yukinobu housed in galleries around the United States, including cities as diverse as New York City, Brooklyn, Minneapolis, and Indianapolis.

Table VI-1: Sample of artworks, their locations and credit lines

\begin{tabular}{|c|c|}
\hline Kiyohara Yukinobu & Fukuda Chiyo-ni \\
\hline $\begin{array}{l}\text { Title: Quail and Millet } \\
\text { Location: MET New York } \\
\text { Credit Line: The Howard Mansfield Collection, } \\
\text { Purchase, Rogers Fund, } 1936\end{array}$ & $\begin{array}{l}\text { Title: Morning Glory Haiku } \\
\text { Location: Matto City Museum/Chiyo-jo Haiku } \\
\text { Museum* } \\
\text { Credit Line: Unknown** }\end{array}$ \\
\hline $\begin{array}{l}\text { Title: Waxwings, Cherry Blossoms, and Bamboo } \\
\text { Location: MET New York } \\
\text { Credit Line: Fishbein-Bender Collection, Gift of } \\
\text { T. Richard Fishbein and Estelle P. Bender, } 2012\end{array}$ & $\begin{array}{l}\text { Title: Cherry blossom haiga } \\
\text { Location: Matto City Museum/Chiyo-jo Haiku } \\
\text { Museum* } \\
\text { Credit Line: Unknown** }\end{array}$ \\
\hline $\begin{array}{l}\text { Title: Asparas } \\
\text { Location: Minneapolis Institute of Art } \\
\text { Credit Line: Donated to the Minneapolis Institute } \\
\text { of Art by the Mary and Jackson Burke Foundation } \\
\text { in } 2015\end{array}$ & $\begin{array}{l}\text { Title: Gourd Haiku } \\
\text { Location: Matto City Museum/Chiyo-jo Haiku } \\
\text { Museum* } \\
\text { Credit Line: Unknown** }\end{array}$ \\
\hline $\begin{array}{l}\text { Title: Monju on a Lion } \\
\text { Location: Minneapolis Institute of Art } \\
\text { Credit Line: Donated to the Minneapolis Institute } \\
\text { of Art by the Mary and Jackson Burke Foundation } \\
\text { in } 2015\end{array}$ & $\begin{array}{l}\text { Title: Self portrait } \\
\text { Location: Nobutaka Aoki Collection } \\
\text { Credit Line: Unknown** }\end{array}$ \\
\hline $\begin{array}{l}\text { Title: Poetess Ono-no-Komachi } \\
\text { Location: Minneapolis Institute of Art } \\
\text { Credit Line: The Christina N. and Swan J. } \\
\text { Turnblad Memorial Fund }\end{array}$ & $\begin{array}{l}\text { Title: Haiku and painting on a low table } \\
\text { Location: Matto City Museum/Chiyo-jo Haiku } \\
\text { Museum* } \\
\text { Credit Line: Unknown** }\end{array}$ \\
\hline $\begin{array}{l}\text { Title: The Four Elegant Pastimes: Amusements in } \\
\text { a Chinese pavilion } \\
\text { Location: Christie's Art Auction } \\
\text { Credit Line: None listed }\end{array}$ & $\begin{array}{l}\text { Title: A haiga on the Hinamatsuri (Doll Festival) } \\
\text { Location: Matto City Museum/Chiyo-jo Haiku } \\
\text { Museum* } \\
\text { Credit Line: Unknown** }\end{array}$ \\
\hline $\begin{array}{l}\text { Title: Two Herrons in the Snow } \\
\text { Location: Indianapolis Museum of Art } \\
\text { Credit Line: Gift of Mr. \& Mrs. J. W. Alsdorf }\end{array}$ & $\begin{array}{l}\text { Title: Bamboo haiga } \\
\text { Location: Matto City Museum/Chiyo-jo Haiku } \\
\text { Museum* } \\
\text { Credit Line: Unknown** }\end{array}$ \\
\hline $\begin{array}{l}\text { Title: Mandarin Duck and Blossoming Plum } \\
\text { Location: Brooklyn Museum } \\
\text { Credit Line: Gift of Howard Hollis }\end{array}$ & $\begin{array}{l}\text { Title: Chiyo-ni’s calligraphed letters to Suejo } \\
\text { Location: Matto City Museum/Chiyo-jo Haiku } \\
\text { Museum* } \\
\text { Credit Line: Unknown** }\end{array}$ \\
\hline \multicolumn{2}{|c|}{$\begin{array}{l}\text { * It is unclear whether the works are housed at Matto City Museum or Chiyo-jo Haiku Museum. The } \\
\text { latter has a permanent exhibit of works, but no information is provided about specific works. } \\
\text { ** This information may exist in Japanese }\end{array}$} \\
\hline
\end{tabular}


Inclusion of Yukinobu's artwork in Euro-American art galleries speaks to her appeal to this audience. Thus, the factors addressed in previous sections did not impact all artists and artworks uniformly. It would be invalid to assert that the experience of women artists was monolithic. Factors such as class, artistic pedigree, format, subject matter, and style seemed to have a great of influence on works chosen by Euro-American collectors and galleries. Nevertheless, the presence of this divide between Yukinobu and Chiyo-ni does indicate that the criterion of Western art theory favors some artists and exclude others. It also indicates a divide between global and local conceptions of Japanese art: while Japanese have access to Chiyo-ni's haiku and haiga, global audiences are exposed to Yukinobu but not Chiyo-ni.

\section{A Global Art History}

In their construction of art history, Japan attempted to "connect to a history of ancient civilization," but not for merely imitating the West. Instead, these attempts were a way of connecting to global feelings through art. Shūzō Takiguchi stated that the 1956 show was not about stylistic internationalism but instead expressed a "deep consciousness of association" and "global consciousness." Another critic argued that international ideas would need to be embraced for a global art scene to grow in Japan. This resulted in several changes to the structure of art schools and artworks.

The efforts of Shuzo Takiguchi and others illuminate a major debate in art scholarship today: to what extent should art history reflect the peculiarities of individual cultures, and to what extent is it universal? This issue is tackled in depth in James Elkins' collection of writings based on his seminar Is Art History Global? In his introduction, the author points out that the emphasis of art history is often finding textual sources that 
coincide with visual ones. These textual sources come from the country of origin and require expertise in that culture to understand, but "its interpretative strategies remain very Western." ${ }^{135}$ Elkins clarifies the question of global art well in the following excerpt: The simple question "Is art history global?" admits two readings. It can be taken as a direct question, open to dispassionate analytical dissection. But it can also be pronounced in a critical and more or less aggressively interrogating manner, suggesting a priori that art history isn't global, and instigating a sense of guilt-in the way that discourse on multiculturalism and globalization, spurred by the spirit of social activism and political correctness, has been attacking humanistic disciplines, curricula, and cultural institutions. ${ }^{136}$

While feeling guilt may not be the reaction that would be more productive for discourse, it is important to discuss issues that arise due to the globalization of art history. Thus, I disagree with the assertion that "political correctness" is the primary motivation of those who question the nature of art history. While I cannot speak for all scholars, many are motivated by a desire for knowledge and understanding. With women artists, it's important to dig deeper into the mechanisms that shaped their experiences and art.

In discussing the current state of art history, Elkins states that art history comes in two incarnations: one meant for international audience, written in English, and one created for locals, in the native language of the region. Local incarnations of art historical

\footnotetext{
${ }^{135}$ James Elkins and Routledge., Is Art History Global? (New York; London: Routledge, 2014), 19.

${ }^{136}$ Ladislav Kesner, "Is a Truly Global Art History Possible?," in Is Art History Global?, ed. James Elkins (New York: Routledge, 2007), 81.
} 
accounts linger due to the desire to preserve "special national qualities" ${ }^{137}$ However, he suggests that it also comes from an "implicit fear that some local, less well-known artists or even certain themes would not be sufficiently interesting for the global art historical community." This certainly seems to have been the case in Japan, in the formative years of World Exhibitions of their art. Such practices of filtering Japanese art, like what was seen with calligraphy, has been perpetuated in Japanese curatorial practices today.

Elkins advocates for art studies that "is to be seen in facilitation of the enjoyment and understanding of art objects, as well as finding some insight into the lives and sensibilities of the people who made and used the art." ${ }^{\text {"138 }}$ Most art historians would likely agree with this assertion, but may disagree with the implementation that would best reach that goal while also remaining faithful to cultural differences. As discussed in the Meiji chapter, art was representative of nations and a source of national pride. Elkins explains that not just Japan, but "every self-respecting new nation had to have its own museums, in which artifacts hitherto identified with social and ritual purposes were redefined so as to be elevated to the new status of 'art' in order that they might compare and compete with the trappings of Western "civilization,"”139 Elkins explains the dominance of Western art traditions with the following statement: "Anglo-American art history is the only tradition that has attempted to account for art globally; others have emerged in

\footnotetext{
${ }^{137}$ Kesner, 85.

${ }^{138}$ Kesner, 102.

${ }^{139}$ Keith Moxey, "Art History After the Global Turn,” in Is Art History Global?, ed. James Elkins (New York: Routledge, 2007), 208.
} 
relation to the indigenous art practices they describe." ${ }^{140}$ In so doing, Elkins does not address the power dynamics at play. When viewed through the lens of Post-colonialism, the cultural power of Euro-Americans can be understood as an extension of literal power. While the efforts Elkins put into opening a dialogue on this topic are admirable, I find his assertions in the essay to be questionable at times.

The second section of the book includes essays and responses to the initial essay and subsequent panel discussion by scholars of various cultures and disciplines. One assessment by Shigemi Inaga titled "A Critical Commentary from a Far Eastern Point of View" illustrates some of the difficulties in adapting a universal concept of art that encompasses Asia. In his opening statement, he uses the dynamics of the event itself to illustrate the difficulties of representing Asian art:

I missed the chance to attend the roundtable. Reading through the transcription of the meeting, I was at the same time frustrated by the fact that I wasn't there, and also relieved. Indeed my absence not only accounts for the difficulty of realizing a global art history at a professional gathering (the total absence of Asians in the panel, which a Japanese alone can hardly cover) but also suggests an invariant of an aesthetic creed or prejudice about Japan: Japanese aesthetics is characterized by its constant failure in or refusal of representing itself whenever occasion is provided. Hence, my absence could be interpreted as a faithful practice of Japanese aesthetics. ${ }^{141}$

While one might disagree with the fatalism implied by his claims that a "faithful practice of Japanese aesthetics" would be to not attempt to explain art from a Japanese perspective, he nevertheless draws attention to the lack of representation of Asian art in

\footnotetext{
${ }^{140}$ Matthew Rampley, "From Big Art Challenge to a Spiritual Vision: What 'Global Art History' Might Really Mean," in Is Art History Global?, ed. James Elkins (New York: Routledge, 2007), 199.

${ }^{141}$ Shigemi Inaga, "Is Art History Globalizable? A Critical Commentary from a Far Eastern Point of View," in Is Art History Global?, ed. James Elkins (New York: Routledge, 2007), 249.
} 
the panel and discussion of global art. He attributes this difficulty to both internal research that "mainly emphasizes old masters and inventories of Buddhist relics" and to the external climate of art history scholarship in which "Orientalists in the West have remained more or less at the periphery"142

Beyond discussing difficulties of dialogue between Western and Asian art scholars, Inaga also addresses the issue of preference. He points out that "most of the Western scholars and amateurs preferred ukiyo-e block prints, whereas this domain of popular imagery in the late Tokugawa period had been scornfully disdained by the Japanese literati class and looked down upon by academic scholars indoctrinated in the classical canon of Western art." ${ }^{\prime 43}$ Thus, there is a disconnect between works preferred by Western scholars and Japanese scholars. Speaking from a Japanese perspective, Inaga merely states this but does not offer explanation.

In his response, Inaga is advocating for a more Japanese way of looking at art, and this is not without precedent. He cites the historical example of Okakura Tenshin, whom he credits as an advocate for Japanese interpretation of art using philosophies like Taoism and Zen Buddhism. There are certainly art historians who specialize in these religious arts, yet the impulse to protect the spiritual foundations of Japanese art were often signored in the process of institutionalizing art in Japan. ${ }^{144}$

\footnotetext{
142 Inaga, 252.

${ }^{143}$ Inaga, 253.

144 Inaga, 256.
} 
While many of the points about the history of Japanese art have been addressed in earlier sections, Inaga makes several points relevant to calligraphy in a global context. First, he describes the difficulty in classification of calligraphy since the traditions in Japan/China and Europe are so different. He describes the importation of Western ideals of art which resulted in a controversy surrounding the decision to include or exclude calligraphy. Further, calligraphy in Japan and China had a different social status than in the West. We see the results of these differences in the treatment of the two artists, Chiyo-ni and Yukinobu, today.

As we have seen, applying a universal conception of "Global Art" to Japan is messy and problematic. Several scholars have addressed the cultural colonization of the museum system that took place in Japan, though no one solution has been proposed and supported universally. Some argue for the adoption of Japanese terminology to better communicate their ideals and aesthetic preferences, while others say Western theory can still be applied to Japan regardless of differing contexts. Global art, though, is not the only topic of discussion among scholars of Japanese art. Feminism and Gender debates surrounding the art of Japan also emerged in the 1990s, sparking further controversy. Gender Debates on Art in Japan

Scholar Ayako Kano credits Chino Kaori with igniting jenda ronso (gender debates) in Japan in the 1990s with a series of talks and later anthology of essays she edited called Onna? Nihon? bi?: arata na jendã hihyõ ni mukete (Women? Japan? Beauty? Toward a New Gender Criticism). ${ }^{145}$ The debates fell into two main categories:

\footnotetext{
${ }^{145}$ Ayako Kano, "Women? Japan? Art?: Chino Kaori and the Feminist Art History Debates," Review of Japanese Culture and Society 15 (2003): 25.
} 
"one that focused on the academic discourse of art history, the other on the contemporary art scene and art exhibits." 146 The use of the question marks in the title show Chino's desire to question basic concepts of women, Japan, and art. While her title focuses mostly on women, she used the term "gender" rather than "feminism" in order to not limit the debate to only women. In opening a talk in 1997, before the anthology was published, Chino said "My talk today is a message intended for people who feel stifled by the conditions of art history studies in Japan today, those who feel like they are suffering and suffocating from lack of air." ${ }^{147}$ She went on to argue that "gender issues are almost totally ignored, not only in art history, but in Japanese academia in general." These statements led to criticism from her male colleagues, one of which being the same Inaga Shigemi cited earlier in the global art section.

Inaga Shigemi responded to Kano's assertion that he was anti-feminist in his short essay, published in 2007, "A Commentary on Ayako Kano's Review of the Feminist Art History Debates.” Inaga clarifies his position as a theoretical disagreement and cites an issue with the translation/summary of his points. He argues that, rather than taking a defensive position to avoid reverse discrimination against men, he was critiquing oversimplification that ignores other gender and sexual minorities in favor of showing "the binary opposition between 'male' and 'female""148 He also supports the reevaluation of models that are often instigated by dominant, male forces that sought to create a

\footnotetext{
${ }^{146}$ Kano, 26.

${ }^{147}$ Kano, 26.

148 Shigemi Inaga, “A Commentary on Ayako Kano’s Review of the Feminist Art History Debates," Review of Japanese Culture and Society 19 (2007): 177.
} 
universal account of art. However, he argues that feminist critique could fall into the same traps of dogmatism as the institutions they oppose. In this way, Inaga seems against changes in art history that seek political correctness and do so by implementing new hierarchies.

Inaga, like Okakura Tenshin, is skeptical of curators that attempt to categorize Japanese art as fine art in the Western/Euro-American sense. As this thesis states, he credits the category of fine art with the "exclusive admission of the "male" and the "categorical exclusion of the "female""149 Thus, Inaga acknowledges that women were excluded from the canon of art history when art was institutionalized during Meiji, describing "official value judgement" as "the process of contagion by which the field of 'normal art history,' among others, has been contaminated"150 In his view, even a feminist art history framework would not be immune from subjective and biased interpretations of art and history. Such an assertion seems to conform with his concept of Japanese aesthetics as not easily defined, especially uniformly. While his writings are largely cautionary, they tend to demand a certain purity and objectivity that does not currently exist in the art history field. Thus, his high standard may be difficult to achieve, even if he acknowledges the need for redefining art history in a less gender biased way.

\footnotetext{
${ }^{149}$ Inaga, 178.

${ }^{150}$ Inaga, 178.
} 


\section{CONCLUSION}

As we have seen, Japanese women have had varying degrees of success in art depending on the political climate and opportunities in Japan at the time. While women of Heian were often be educated in painting and produced works like the famous Genji Monogatari, women of the Kamakura to Azuchi-Momoyama periods were ousted from the art world altogether. In Edo, conditions again became favorable for women to excel, not only as hobbyists, but as professional artists. Chiyo-ni and Yukinobu, as professional women artists, were a product of this era and their own creativity and determination.

Ideals during Edo were especially restrictive to women. However, the same NeoConfucian ideology that stifled women also gave them more access to education, which led to increased opportunities in fields that had been dominated by men. Women artists were featured in publications and accepted commissions for their work, and both Chiyoni and Yukinobu survived as single, professional artists. Despite recognition during their lifetime, both women have been largely neglected in art historical accounts and gallery collections.

The Meiji era in Japan was a period of dramatic change to the art world that further neglected women artists for political reasons. During this time, exposure to EuroAmerican thought and artistic artifacts led Japan to shift their focus to implement bunmei kaika. Bijutsu, the new term for art of this era, was marketed to a more international audience. Further, efforts were made to preserve artworks of the past and construct art historical accounts of these works. This led to winners and losers in the art scene, and women artists that had previously been recognized were especially impacted as the criterion of "good" art changed. In this way, Japan, which admittedly had its own issues 
with women's roles in Japan, inherited the West's infatuation with the male Masters in the domain of art. The Masters they chose were often the iemoto of art schools and were valued for their innovation. While changes continued beyond Meiji, this era laid the foundation for a hierarchy of art that is still very much a part of art exhibits and museums in Japan today.

It was during this time that decisions were made that still impact audiences inside and outside Japan. Because the artwork of Yukinobu conforms much more easily to European ideals of art, many works by Yukinobu were obtained by Western curators and art critics and now exist in galleries in the United States and Europe. Chiyo-ni's artworks were more difficult for these audiences to categorize and reconcile. As such, all haiga by Chiyo-ni still reside in museums in Matto City, Japan, her hometown. In this way, European/American audiences viewed a different picture of Japanese art than Japanese. This global vs. local dynamic was a byproduct of external and internal pressures on Japan that began in Meiji and are still seen today.

There are certainly opportunities for further research on this topic. The analysis provided in this thesis could be applied to other female artists of Japan. Further, it would be worthwhile to visit regional art museums in Japan and the United States and speak with curators/art groups about their selection processes, acquisition of works, and specific exhibits at the museum. There could also be a larger sampling of artworks polled to determine wider trends in the treatment of works by Japanese female artists. Since much of this research is qualitative, it could be further enhanced by providing more quantitative data though surveys or other data gathering methods. 
While Europe and the United States did not introduce art preservation and archives to Japan, it did shape modern "universal" art history endeavors in early Meiji and the formation of art institutions. In Liberating Culture: Cross-Cultural Perspectives on Museums, Curation and Heritage Preservation, researcher Christina F. Kreps points out that "non-western models of museum and curatorial practices escaped the attention of western scholars and museologists. This lack of attention is not only a reflection of an ideology that views the museum and museological behavior as uniquely western, but also a belief in the superiority of western, scientifically based museology and systems of cultural heritage preservation."151 If one agrees that art reflects culture, art museums should ideally also be modelled after the values of the culture in which they belong. However, the European and American desire to understand Japanese culture has led to "the act of detaching them from their original cultural context and recontextualizing them in to western scientific frames of reference."152 This mechanism of cultural detachment may not be reversible, but it can be acknowledged as a reality.

Going forward, it would be worthwhile to engage Japanese people in developing exhibits and descriptions of Japanese art. The International Council of Museums (ICOM), of which Japanese is a member, provides the following definition for a museum; "a nonprofit making, permanent institution in service to society and its development, and open to the public which acquires, conserves, researches, communicates and exhibits, for the purpose of study, education and enjoyment, material evidence of people and their

\footnotetext{
${ }^{151}$ Christina F. Kreps, Liberating Culture: Cross-Cultural Perspectives on Museums, Curation, and Heritage Preservation (London; New York: Routledge, 2003), 1.

${ }^{152}$ Kreps, 30.
} 
environment" 153 While museums and galleries around the world follow these principles, there is still more work that could be done to enhance such endeavors and increase awareness of the limitations of this definition and the problematic nature of acquisition and preservation of artworks of Japan.

Issues of globality, gender, and post-colonialism will not be resolved by simply discussing them. Instead, steps must be taken to proactively revise outmoded models that favor the male and existing power structures. Galleries, museums and art historians must examine their assumptions and expectations. Notable women artists should not be shown in merely a tokenistic manner, as part of a show dedicated to women, but alongside the male iemoto they studied under. Only then can a complete picture of the cultural history of Japan be created, and artists like Chiyo-ni and Yukinobu given due recognition for their achievements in this post-modern age.

${ }^{153}$ Kreps, 21. 


\section{References}

“About Chiyo-Jo Haiku Museum | Chiyo-Jo Haiku Museum.” Accessed April 8, 2017. http://haikukan.city.hakusan.ishikawa.jp/english/about/index.html.

Arnove, Robert F., and Ryohei Matsuda. "Japanese 'Living National Treasures' in the Arts." Education and Society 27, no. 2 (2009): 45-54.

Baird, Merrily. Symbols of Japan : Thematic Motifs in Art and Design. New York: Rizzoli, 2001.

Bary, Wm. Theodore de, Donald Keene, George Tanabe, and Paul Varley. "Sources of Japanese Tradition." In Sources of Japanese Tradition, 2nd ed., 1:399-425. New York Chichester: Columbia University Press, 2001.

Bourdieu, Pierre, and Randal Johnson. The Field of Cultural Production : Essays on Art and Literature. Cambridge: Polity Press, 2016.

Brecher, W. Puck. The Aesthetics of Strangeness Eccentricity and Madness in Early Modern Japan. Honolulu: University of Hawai'i Press, 2013.

Brown, Kendall H. The Politics of Reclusion : Painting and Power in Momoyama Japan. Honolulu: University of Hawai'i Press, 1997.

Buckland, Rosina. Painting Nature for the Nation: Taki Katei and the Challenges to Sinophile Culture in Meiji Japan. Brill, 2012.

Bundy, R. "Gendering the Court Woman Poet: Pedigree and Portrayal in Fukuro Zoshi." Monumenta Nipponica 67, no. 2 (2012): 201-38.

Copeland, Rebecca L., and Esperanza. Ramirez-Christensen. Father-Daughter Plot : Japanese Literary Women and the Law of the Father. University of Hawaii Press, 2001.

Donegan, Patricia, Chiyo ni, Chiyo ni Selections English 1998, and Yoshie Ishibashi. Chiyo-Ni : Woman Haiku Master. 1st ed. Boston, MA: Tuttle Publishing, 1998.

Elkins, James, and Routledge. Is Art History Global? New York; London: Routledge, 2014.

Fister, Pat, Helen Foresman Spencer Museum of Art, Honolulu Academy of Arts, and Fumiko Y. Yamamoto. Japanese Women Artists, 1600-1900. 1st ed. Lawrence: Spencer Museum of Art, University of Kansas, 1988.

"Flying Celestial, Kiyohara Yukinobu ^ Minneapolis Institute of Art." Accessed February 28, 2018. http://collections.artsmia.org/art/122129/flying-celestialkiyohara-yukinobu. 
Gerhart, Karen M. “Eyes of Power : Art and Early Tokugawa Authority.,” 2000. http://public.eblib.com/choice/publicfullrecord.aspx?p=3413054.

- The Eyes of Power : Art and Early Tokugawa Authority. Honolulu: University of Hawai'i Press, 1999.

Greenberg, Clement. Avantgarde Und Kitsch. na, 1939. http://sculpture.artapsu.com/wpcontent/uploads/2013/01/Greenberg-AvGdKtch.pdf.

Hume, David. "Of the Standard of Taste." In The Nature of Art : An Anthology, edited by Thomas E. Wartenberg, 1st ed. Boston, MA: Wadsworth Cengage Learning, 2012 .

Inaga, Shigemi. "A Commentary on Ayako Kano's Review of the Feminist Art History Debates." Review of Japanese Culture and Society 19 (2007): 175-80.

. "Is Art History Globalizable? A Critical Commentary from a Far Eastern Point of View." In Is Art History Global?, edited by James Elkins, 249-89. New York: Routledge, 2007.

Japanese, 1643 - 1682, Kiyohara Yukinobu, and Kiyohara Yukinobu. Monju on a Lion. second half 17th century. Hanging scroll; Ink and color on silk, Height: 24 in $(60.9 \mathrm{~cm})$; Width: 14.1 in $(35.8 \mathrm{~cm})$ (image). Minneapolis Institute of Art. https://commons.wikimedia.org/wiki/File:KiyoharaYukinobu_MonjuOnALion_M IA_L20153371.jpg.

Kano, Ayako. "Women? Japan? Art?: Chino Kaori and the Feminist Art History Debates." Review of Japanese Culture and Society 15 (2003): 25-38.

Kant, Immanuel. "The Critique of Judgment: The Aesthetic Representation of the Finality of Nature." In The Nature of Art : An Anthology, edited by Thomas E. Wartenberg, 1st ed. Boston, MA: Wadsworth Cengage Learning, 2012.

Kesner, Ladislav. "Is a Truly Global Art History Possible?” In Is Art History Global?, edited by James Elkins, 81-111. New York: Routledge, 2007.

Kitahara, Michio. "The Rise of the Four Mottoes in Japan: Before and After the Meiji Restoration." Journal of Asian History 20, no. 1 (1986): 54-64.

Kreps, Christina F. Liberating Culture : Cross-Cultural Perspectives on Museums, Curation, and Heritage Preservation. London; New York: Routledge, 2003.

"Kuniyoshi Project." Accessed May 14, 2018. http://www.kuniyoshiproject.com/Mirror\%20of\%20Women\%20of\%20Wisdom\% 20and\%20Courage.htm.

Mamine, Tomoko. "Displaying Globality.” Third Text 27, no. 4 (2013): 502-9. 
Marra, Michele. Japanese Hermeneutics : Current Debates on Aesthetics and Interpretation. Honolulu (T.H.): University of Hawai'i Press, 2002.

Maruyama, Masao. Studies in Intellectual History of Tokugawa Japan. Princeton: Princeton University Press, 2016.

Morishita, Masaaki. "The Empty Museum : Western Cultures and the Artistic Field in Modern Japan,” 2016. https://nls.ldls.org.uk/welcome.html?ark:/81055/vdc_100029782442.0x000001.

"Morning Glory Symbolism \& the Meaning of Morning Glories in the Language of Flowers." Accessed April 9, 2017. http://livingartsoriginals.com/flowermorningglory.htm.

Morphy, Howard. Becoming Art: Exploring Cross-Cultural Categories. Oxford ; New York: Berg, 2007. http://www.loc.gov/catdir/enhancements/fy0743/2007033738b.html.

Moxey, Keith. "Art History After the Global Turn.” In Is Art History Global?, edited by James Elkins, 207-14. New York: Routledge, 2007.

Murase, Miyeko., Mary Griggs. Burke, and N.Y. Metropolitan Museum of Art, New York. "Bridge of Dreams : The Mary Griggs Burke Collection of Japanese Art," 2000. http://catalog.hathitrust.org/api/volumes/oclc/42765071.html.

Nochlin, Linda. "Why Have There Been No Great Women Artists?" In Women, Art and Power, 145-78, 1988.

Ortiz, Fernando. Cuban Counterpoint: Tobacco and Sugar. Durham and London: Duke University Press, 1995. http://www.personal.psu.edu/users/s/a/sam50/readings521/ORTIZ_CounterEngl.pdf.

"Peony." Museum of Fine Arts, Boston, May 29, 2018. https://www.mfa.org/collections/object/peony-26006.

Rampley, Matthew. "From Big Art Challenge to a Spiritual Vision: What 'Global Art History' Might Really Mean.” In Is Art History Global?, edited by James Elkins, 188-222. New York: Routledge, 2007.

Richie, Donald. The Honorable Visitors. New York; Tokyo: ICG Muse, 2001.

Sato, Doshin., Hiroshi Nara, and Getty Research Institute (CA). Modern Japanese Art and the Meiji State: The Politics of Beauty. Los Angeles: Getty Research Institute, 2011. 
Screech, Timon. Obtaining Images : Art, Production and Display in Edo Japan. Honolulu: University of Hawai'i Press, 2012.

Shimizu, Yoshiaki. Japan: The Shaping of Daimyo Culture 1185-1868. Washington, D.C.: National Gallery of Art, 1988.

Surak, Kristin. "From Selling Tea to Selling Japaneseness: Symbolic Power and the Nationalization of Cultural Practices." European Journal of Sociology 52, no. 02 (August 2011): 175-208. https://doi.org/10.1017/S0003975611000087.

Suzuki, Daisetz T. Zen and Japanese Culture: With a New Introduction by Richard Jaff. Princeton, N.J.: Princeton University Press, 2010.

Tanizaki, Jun'ichirō, Thomas J. Harper, Charles Moore, and Edward G. Seidensticker. In Praise of Shadows. New Haven, Conn: Leete's Island Books, 1977.

"Vienna International Exposition and Japonism | Part 1: Expositions Held in and before 1900 | Expositions, Where the Modern Technology of the Times Was Exhibited." Accessed September 3, 2018. http://www.ndl.go.jp/exposition/e/s1/1873-2.html.

Weidner, Marsha Smith. Flowering in the Shadows: Women in the History of Chinese and Japanese Painting. Honolulu: University of Hawaii Press, 1990.

"Yang Guifei." Museum of Fine Arts, Boston, January 31, 2017. https://www.mfa.org/collections/object/yang-guifei-26001.

"Yang Guifei Giving Her Hair Ornaments to a Messenger." Museum of Fine Arts, Boston, January 31, 2017. http://www.mfa.org/collections/object/yang-guifeigiving-her-hair-ornaments-to-a-messenger-24919.

第三版, 日本大百科全書 (ニッポニカ), 世界大百科事典内言及ブリタニカ国際大百科事典 小項目 事典.“千代女(ちよじょ)とは.” コトバンク. Accessed May 8, 2018. https://kotobank.jp/word/\%E5\%8D\%83\%E4\%BB\%A3\%E5\%A5\%B3-98376. 